\title{
The Relative Binding Position of Nck and Grb2 Adaptors Dramatically Impacts Actin-Based Motility of Vaccinia Virus
}

Angika Basant* and Michael Way*

5 Cellular signalling and cytoskeletal function laboratory, The Francis Crick Institute, 1 Midland Road, London, NW1 1AT, UK

*Co-corresponding. Email: angika.basant@crick.ac.uk and michael.way@crick.ac.uk Running title: The role of adaptor position in signalling output

10

\section{ABSTRACT}

Phosphotyrosine (pTyr) motifs in unstructured polypeptides orchestrate important cellular processes by engaging $\mathrm{SH}$-containing adaptors to nucleate complex signalling networks.

15 The concept of phase separation has recently changed our appreciation of such multivalent networks, however, the role of pTyr motif positioning in their function remains to be explored. We have now explored this parameter in the assembly and operation of the signalling cascade driving actin-based motility and spread of Vaccinia virus. This network involves two pTyr motifs in the viral protein A36 that recruit the adaptors Nck and Grb2 upstream of N-WASP and Arp2/3-mediated actin polymerization. We generated synthetic networks on Vaccinia by manipulating pTyr motifs in A36 and the unrelated p14 from Orthoreovirus. In contrast to predictions, we find that only specific spatial arrangements of Grb2 and Nck binding sites result in robust N-WASP recruitment, Arp2/3 driven actin polymerization and viral spread. Our results suggest that the relative position of pTyr

25 adaptor binding sites is optimised for signal output. This finding may explain why the relative positions of pTyr motifs are usually conserved in proteins from widely different species. It also has important implications for regulation of physiological networks, including those that undergo phase transitions. 


\section{INTRODUCTION}

Multicellular animals extensively use phosphotyrosine (pTyr) signals for growth, communication, movement and differentiation (Jin and Pawson, 2012; Lim and Pawson, 2010). Pathways including EGF and insulin receptor signalling, as well as T cell activation

35 rely on pTyr motifs interacting with SH2 domains (Blumenthal and Burkhardt, 2020; Lemmon and Schlessinger, 2010). SH2 domains are present in kinases, phosphatases as well as adaptor proteins that lack enzymatic activity but couple upstream signalling events to downstream function (Liu and Nash, 2012). Examples of such adaptors include Shc1, Crk, Nck and Grb2 that also contain other interaction modules including SH3 domains that bind 40 polyproline motifs (Bywaters and Rivera, 2021; Mayer, 2015). pTyr signalling is often dysregulated in cancers and other diseases. For example, EGF receptors can be mutationally activated or present in high copy numbers vis-à-vis their cognate adaptors, and oncogenic mutations frequently map to SH2 domains (Li et al., 2012a; Li et al., 2021; Shi et al., 2016; Sigismund et al., 2017). It therefore remains important to understand the molecular 45 principles of how pTyr signalling networks function.

pTyr motifs commonly occur in poorly ordered, unstructured regions of proteins (Stavropoulos et al., 2012; Van Roey et al., 2013). Moreover, a single polypeptide may be phosphorylated more than once to generate multiple $\mathrm{SH} 2$ domain binding sites creating a large network of interactions with many signalling modules. Indeed, like many receptor

50 tyrosine kinases, the $C$ terminus of EGFR is disordered (Figure 1 - supplement $1 \mathrm{~A}$ ) (Keppel et al., 2017; Pinet et al., 2021). This region contains several pTyr motifs including those that bind Grb2 and Shc1 (Batzer et al., 2006; Lin et al., 2019; Mandiyan et al., 1996; Smith et al., 2006; Ward et al., 1996). The relative positions of these motifs are conserved across vertebrates (Figure 1 - supplement 1B). Though they are short and space-efficient, linear motifs bearing such pTyr must interact with effectors comprising globular domains of varying sizes. Additionally, disordered sequences can become structured when bound to their respective domains (Davey, 2019; Nioche et al., 2002; van der Lee et al., 2013). Given that such factors are likely to impose constraints or "polarity" on the architecture of signalling networks, can the positioning of motifs have an impact on function? If yes, this 
60 would suggest that pTyr motifs cannot be repositioned as they are optimised to achieve the desired signalling output.

In recent years, the framework of phase separation or biomolecular condensates has shed new light on signalling network organization (Banani et al., 2017; Huang et al., 2019; Li et al., 2012b; Zhao and Zhang, 2020). Integral membrane proteins with disordered cytoplasmic regions and involved in multivalent pTyr-SH2 interactions such as Linker for Activation of T cells (LAT) and the kidney podocyte regulator nephrin form phase separated condensates at critical concentrations (Case et al., 2019; Ditlev et al., 2019; Kim et al., 2019; Pak et al., 2016; Su et al., 2016). This striking property is thought to contribute to their signalling function. As these proteins have been largely investigated by overexpressing components

70 in cells or by reconstitution in vitro, we are yet to fully understand how the underlying principles of condensate organisation regulate physiological signalling (Alberti et al., 2019; Mayer and Yu, 2018; McSwiggen et al., 2019). Furthermore, the relationship between pTyr motifs in these systems has only been explored via disruption of the sites by a mutational approach (Huang et al., 2017) and the role of their positioning has never been investigated.

75 Do membrane signalling proteins make stochastic connections with their downstream components or do underlying wiring principles exist? We chose to address the importance of pTyr motif positioning in a physiologically relevant model, that of Vaccinia virus egress from its infected host cell (Leite and Way, 2015).

Following replication and assembly, Vaccinia virus recruits kinesin-1 via WD/WE motifs in 80 the cytoplasmic tail of A36 an integral viral membrane protein to transport virions to the cell periphery on microtubules (Dodding et al., 2011) (Figure 1). After viral fusion with the plasma membrane, extracellular virions that remain attached to the cell locally activate Src and Abl family kinases (Frischknecht et al., 1999; Newsome et al., 2004; Newsome et al., 2006; Reeves et al., 2005). This results in phosphorylation of tyrosine 112 and 132 in a 85 disordered region of A36 once it incorporates into the plasma membrane when the virus fuses at the cell edge (Frischknecht et al., 1999; Newsome et al., 2004; Newsome et al., 2006; Reeves et al., 2005; Ward and Moss, 2004) (Figure 1 \& Figure 1 - supplement 1C). 
bioRxiv preprint doi: https://doi.org/10.1101/2021.10.07.463509; this version posted October 8, 2021. The copyright holder for this preprint

(which was not certified by peer review) is the author/funder, who has granted bioRxiv a license to display the preprint in perpetuity. It is made available under aCC-BY 4.0 International license.

pTyr 112 and 132 motifs bind the SH2 domains of adaptors Nck and Grb2 respectively (Scaplehorn et al., 2002). Nck recruits N-WASP via WIP to activate the Arp2/3 complex at the virus (Donnelly et al., 2013). The resulting actin polymerisation drives virus motility and enhances its cell-to-cell spread (Ward and Moss, 2004). Nck is essential for actin tail formation, while Grb2 recruitment helps stabilise the signalling complex (Frischknecht et al., 1999; Scaplehorn et al., 2002; Weisswange et al., 2009). Additionally, NPF motifs in A36 interact with the RhoGEF intersectin to recruit Cdc42 and clathrin to the virus, further enhancing actin polymerisation (Humphries et al., 2012; Humphries et al., 2014; Snetkov et al., 2016) (Figure 1). The turnover rates of Nck, Grb2 and N-WASP beneath extracellular virions are highly reproducible with little variability, suggesting the signalling network has a defined organisation (Weisswange et al., 2009). This underlying signalling network organization may arise from the fact that both WIP and N-WASP only have two Nck-binding 100 sites, each with distinct preferences for the three adaptor SH3 domains (Donnelly et al., 2013). This Nck-dependent signalling network is not unique to Vaccinia and is also used to polymerise actin by nephrin in kidney podocytes and the pathogenic $E$. coli EPEC protein Tir (Hayward et al., 2006; Jones et al., 2006; Welch and Way, 2013).

Cellular pTyr networks are typically transient and can be difficult to detect, making them 105 challenging to manipulate and study quantitatively. In contrast, the Vaccinia virus signalling network and actin tail formation are robust and sustained. Vaccinia therefore provides an in vivo genetically tractable system where outputs of actin polymerisation, virus speed and spread can be quantitatively measured. Using recombinant Vaccinia viruses, including ones expressing Orthoreovirus protein p14 (Figure 1 - supplement $1 \mathrm{C}$ ), we uncovered a striking

110 impairment in actin-based motility and spread of the virus when the relative positions of Nck and Grb2 pTyr binding motifs were exchanged and/or manipulated. Collectively our results indicate that the relative positioning of pTyr motifs and downstream adaptor binding is an important factor in the output of signalling networks that has thus far been overlooked. 


\section{RESULTS}

\section{A minimal Vaccinia system to investigate how pTyr signalling regulates actin polymerization.}

120 The recruitment of Nck by A36 at pTyr112 is necessary and sufficient to drive actin-based motility of Vaccinia virus whereas Grb2 recruitment at pY132 improves actin tail formation (Frischknecht et al., 1999; Scaplehorn et al., 2002; Weisswange et al., 2009). In addition to these two adaptors, the recruitment of intersectin, Cdc42 and clathrin by full-length A36 also indirectly regulates the extent of virus-driven actin polymerisation (Humphries et al.,

125 2012; Humphries et al., 2014; Snetkov et al., 2016)2014; Snetkov et al., 2016). To reduce the complexity arising from these interactions and other unknown A36 binding partners, we generated a recombinant virus that recruits a minimal signalling network to activate Arp2/3-dependent actin polymerisation (Figure 1). To achieve this goal, the WR- $\triangle A 36 R$ virus lacking the $A 36$ gene was rescued with an A36 variant that terminates after the Grb2

130 binding site at residue 139 (referred to as the A36 N-G virus hereafter). This shorter A36 variant retains the WD/WE kinesin-1 binding motifs that are required for microtubule-based transport of the virus to the plasma membrane. As in the full-length protein, actin tail formation induced by this shorter A36 variant is dependent on the Nck-binding site (Figure 2 - supplement 1A, A36 N-G vs X-G). Similar to the full-length protein (Scaplehorn et al.,

135 2002), truncated A36 induces shorter actin tails in the absence of Grb2 recruitment (Figure 2 - supplement $1 \mathrm{~A}, \mathrm{~A} 36 \mathrm{~N}-\mathrm{G}$ vs N-X). Having confirmed the role of Nck and Grb2 is the same as in the wild-type virus, we used the A36 N-G virus to explore the role of pTyr motif positioning in signalling output.

140 The relative positioning of $\mathbf{N c k}$ and Grb2-binding has a dramatic impact on actin polymerization.

Residues N-terminal to the Tyr (positions -4 to -1 ) are important for tyrosine kinase site recognition while SH 2 domain binding specificity is typically based on +1 to +6 residues Cterminal to the pTyr (Blasutig et al., 2008; Frese et al., 2006; Kefalas et al., 2018; Songyang 145 and Cantley, 1995; Wagner et al., 2013). Given these previous observations, we compared 
actin polymerisation, virus motility and spread of the $A 36 \mathrm{~N}-\mathrm{G}$ virus with a recombinant virus where 12 residues surrounding the pTyr112 Nck-binding site were exchanged with the pTyr132 Grb2 interaction motif (Figure 2A, A36 G-N virus hereafter). Our modified virus thus maintains requirements for Src and Abl mediated phosphorylation as well as Nck and Grb2

$150 \mathrm{SH} 2$ binding. Strikingly, exchanging the positions of these two pTyr motifs has a dramatic impact on actin tail length though the number of extracellular virus particles inducing actin polymerization remains unaltered (Figure $2 \mathrm{~B}$ ). It is possible that this effect is a consequence of the relative positioning of the two adaptor binding sites in A36. Alternatively, it may be that the Nck-binding site is sub-optimal when it is repositioned into the Grb2-binding locus.

155 To determine which is true, we assessed the impact of changing the position of the Nckbinding site in the absence of Grb2 recruitment. We found that viruses $A 36 \mathrm{~N}-\mathrm{X}$ and $\mathrm{X}-\mathrm{N}$ that lack a Grb2 binding site (N-X: Nck binds in native position and X-N: Nck binds in Grb2 position), did not differ in their extent or ability to induce actin tails (Figure 2 - supplement 1B). This indicates that relative positioning of the Nck and Grb2 phosphotyrosine motifs in

160 A36 is important for optimal signalling output (efficient actin polymerization). Actin polymerisation at the virus drives both the motility and spread of virions. To test whether motif positioning had an impact on the former, we imaged cells infected with the A36 N-G or A36 G-N viruses expressing A3, a viral core protein tagged with RFP. In the swapped configuration, corresponding to reduced actin polymerisation, virus motility is slower

165 (Figure 2C, Supplemental Movie 1). In addition, the A36 G-N virus has reduced cell-to-cell spread as it forms smaller plaques on confluent cell monolayers compared to A36 N-G (Figure 2D). Our observations with Vaccinia clearly demonstrate that the output of a signalling network is strongly influenced by the relative positioning of Nck and Grb2 binding sites in the membrane protein responsible for initiating the signalling cascade.

\section{Inducing actin polymerization using a synthetic signalling network.}

We were curious whether our observations were unique to Vaccinia A36 and/or if the positioning of adaptor binding sites would also be important in a different context. We took advantage of the Vaccinia signalling platform to generate a synthetic pTyr network that 
175 replaces A36 with a different protein capable of activating actin polymerization via the same adaptors. Recent observations demonstrate that p14, an integral membrane protein from Orthoreovirus activates N-WASP via Grb2 to regulate cell fusion (Chan et al., 2020). Grb2 is recruited by a pTyr116 motif located in the short cytoplasmic tail of p14 that is also predicted to be disordered (Figure 1 - supplement $1 \mathrm{C}$ ). Interestingly, examination of the p14 sequence reveals there are two tyrosine residues located 16 and 20 amino acids upstream of the pTyr116 that are predicted to interact with Nck (Eukaryotic Linear Motif (ELM) and Scansite 4.0) (Kumar et al., 2019; Obenauer et al., 2003) (Figure 3A). To examine whether these sites participate in actin polymerization we generated a hybrid construct comprising the first 105 amino acids of A36 including the kinesin-1-binding motifs required

185 to traffic virions to the plasma membrane and residues $79-125$ of p14 (Figure 3A). Transient expression of p14 N-G in cells infected with Vaccinia virus lacking A36 results in extracellular virions inducing robust actin tails that were dependent on the presence of N-WASP (Figure 3B and C). Given this, we mutated Tyr96, 100 and 116 of p14 in turn and examined the impact on actin tail formation. This analysis reveals there is no role for Tyr100 as its 190 mutation to phenylalanine had no impact on actin tail formation (Figure 3D). In contrast, Tyr96 is essential for the virus induced actin polymerization. As with Vaccinia A36, the ability of transiently expressed p14 N-G to promote actin polymerization primarily depends on the predicted Nck-binding pTyr96 and is enhanced by pTyr116, which is a bona fide Grb2 binding site (Chan et al., 2020) (Figure 3D and E). To confirm whether pTyr96 interacts with 195 Nck, we incubated HeLa cell lysates with beads conjugated with peptides containing the prospective binding motif. The pTyr96 peptide retains Nck from the cell lysate but not the unphosphorylated control (Figure 3F). Our observations clearly demonstrate that as with Vaccinia A36, p14 of Orthoreovirus induces actin polymerization using a Nck and Grb2 signalling network. These results also establish that the Vaccinia platform can be used to 200 analyze synthetic signalling networks and test predictions concerning their operation.

Given this, we generated a recombinant virus where endogenous A36 was replaced with the hybrid A36-p14 protein (henceforth referred to as the p14 N-G virus). As we have 
bioRxiv preprint doi: https://doi.org/10.1101/2021.10.07.463509; this version posted October 8, 2021. The copyright holder for this preprint

(which was not certified by peer review) is the author/funder, who has granted bioRxiv a license to display the preprint in perpetuity. It is made available under aCC-BY 4.0 International license.

observed with Vaccinia A36, actin tails generated by the p14 N-G virus recruit endogenous

205 Nck, WIP and N-WASP to the virion (Figure 4A). In the absence of an antibody that can detect Grb2, we confirmed the p14 N-G virus also recruits Grb2 by infecting HeLa cells stably expressing GFP-Grb2 (Figure 4A) (Figure 4 - supplement 1). We next sought to determine whether the relative positioning of the Nck and Grb2 binding sites was important for the signalling output of the $\mathrm{p} 14$. We therefore generated a recombinant virus (p14 G-N virus)

210 where the Nck- and Grb2-binding motifs of p14 are in a swapped orientation (Figure 4B). Remarkably, as we observed for A36, swapping these motifs did not impact on the number of viruses inducing actin polymerization but resulted in shorter actin tails and a slower virus speed (Figure 4C and D, Supplemental Movie 2). Plaque assays on confluent cell monolayers reveals that the p14 G-N virus is also attenuated in its spread (Figure 4E). Once again, the

215 signalling output of the system clearly depends on the relative positioning of Nck and Grb2 pTyr binding sites.

\section{Why does the relative position of Nck- and Grb2-binding sites impact actin polymerization?}

220 To further probe into how pTyr motif positioning impacts signalling output, we focused on the A36 signalling network given we have a deeper understanding of how it functions. The simplest explanation for the difference between the signalling output of the $\mathrm{N}-\mathrm{G}$ and $\mathrm{G}-\mathrm{N}$ configurations is that the levels of A36 are different between the two viruses. To examine if this is the case, we generated recombinant viruses where the $A 36 \mathrm{~N}-\mathrm{G}$ and $\mathrm{G}-\mathrm{N}$ variants

225 were tagged at their C-terminus with tgGFP2. We measured the fluorescent intensity ratio of tgGFP2 to the viral core protein A3 fused to RFP. RFP-A3 provides a reliable internal reference marker as its fluorescent intensity is consistent across different viruses and cell lines expressing GFP-tagged components of the Vaccinia signalling network (Figure 5 supplement 1A). We found no significant difference between the levels of A36 N-G and G-

$230 \quad \mathrm{~N}$ relative to RFP-A3 (Figure 5 - supplement 1B). This suggests that underlying cause for the difference in signalling output resides in the network itself. We therefore determined the level of recruitment of the components involved in activating the Arp2/3 complex on the 
virus. We infected HeLa cells stably expressing GFP-tagged Nck, Grb2, WIP or N-WASP (Figure 4-supplement 1) and measured their respective GFP intensities on the virus relative 235 to RFP-A3 as an internal fluorescent standard. We found that the levels of Nck are comparable between the $\mathrm{A} 36 \mathrm{~N}-\mathrm{G}$ and G-N viruses (Figure 5A). In contrast, Grb2 and NWASP were significantly reduced on the G-N virus (Figure 5A). The level of WIP, which is also recruited to actin tails is also lower in the G-N configuration (Figure 5 - supplement 1C). To confirm these results, we also took advantage of MEF cell lines stably expressing

240 GFP-tagged Nck- or N-WASP but lacking their respective endogenous proteins (Figure 5 supplement 2). We found that as seen in HeLa cells, the levels of GFP-Nck were similar for both viruses but the A36 G-N virus recruited two-fold less GFP-N-WASP than the N-G variant (Figure 5B). It is possible that the reduction in N-WASP is a consequence of lower Grb2 levels as this adaptor helps stabilize N-WASP on the virus (Weisswange et al., 2009). To

245 examine this possibility, we measured N-WASP levels on a virus where the Grb2-binding site is abolished by a Tyr132 to Phe mutation (A36 N-X virus). Loss of Grb2 binding had no appreciable impact on the levels of Nck on the A36 N-X virus as compared to those on the A36 N-G and G-N viruses (Figure 5C). The levels of N-WASP on the A36 N-X virus were reduced (46.4\%) but not to the same extent as the A36 G-N virus (75\%). Repositioning the

250 Nck and Grb2 sites clearly leads to a more severe impairment of the ability of the signalling network to activate Arp2/3 driven actin polymerization than loss of the Grb2 site. Moreover, this suggests that Grb2 has a dominant negative effect when it is mis-positioned relative to Nck.

255 Reduced Grb2 recruitment is not due to diminished phosphorylation of Tyrosine 132.

The comparable levels of Nck recruitment to the A36 N-G and G-N viruses suggests that phosphorylation of Tyr112 (the Nck-binding site) is not impacted by changing its position within A36. However, as Grb2 recruitment is impaired we sought to determine whether its binding site (Tyr132) is less phosphorylated in the G-N virus. During Vaccinia infection, only 260 a small fraction of the total cellular A36 is phosphorylated by Src and Abl family kinases when the virus fuses with host plasma membrane during its egress (Newsome et al., 2004). 
To ensure we examined the relevant population of A36, we directly looked at the level of Tyr132 phosphorylation associated with individual virions inducing actin tails using an antibody that detects pTyr132 (Newsome et al., 2004). We found that the antibody labels

265 A36 N-G and G-N but not N-X (negative control lacking Grb2 binding site) virus particles inducing actin tails (Figure 6A). The lack of labelling of the $\mathrm{N}-\mathrm{X}$ virus demonstrates that the antibody is specific as it does not detect any other phosphorylated component in the signalling network involved in nucleating actin tails. Moreover, the intensity of labelling was significantly higher on the G-N compared to the N-G virus, suggesting there is no

270 impairment in phosphorylation. This enhanced labelling intensity most likely reflects increased antibody access to its pTyr132 epitope in the absence of Grb2 recruitment. To test this possibility, we determined the level of pTyr132 antibody labelling on the A36 N-G virus when Grb2 was knocked down using siRNA. Consistent with our hypothesis, we found that a reduction in levels of Grb2 results in increased labelling on the A36 N-G virus $275(p=0.071$, Figure 6B). This increase was less dramatic than the $\mathrm{G}-\mathrm{N}$ virus as the knockdown was not complete and the virus is good at recruiting any remaining Grb2. Taken together, our observations suggest that the lower levels of Grb2 recruitment observed when its binding site is repositioned are a consequence of changes in the signalling network rather than a reduction in phosphorylation of Tyr132.

\section{Position rather than the number of Grb2 sites influences signalling network output.}

Our data indicate that the reduced signalling output of the A36 G-N virus is linked to decreased levels of Grb2 in the signalling network. This suggests that the position of Grb2 binding relative to $\mathrm{Nck}$ is the critical factor influencing the functional outcome of the

285 network formed by the A36 G-N virus. We therefore wondered what impact an additional Grb2 site would have on virus-induced actin polymerization? More importantly, would any improvement in signalling output be dependent on the position of this second Grb2 site relative to Nck binding? To address this question, we generated recombinant G-N viruses expressing A36 with an extra Grb2 site N-terminal (A36 G-G-N virus) or C-terminal (A36 G$290 \mathrm{~N}-\mathrm{G}$ virus) to the Nck site (Figure 7A). All four viruses (N-G, G-N, G-N-G and G-G-N) recruited 
bioRxiv preprint doi: https://doi.org/10.1101/2021.10.07.463509; this version posted October 8, 2021. The copyright holder for this preprint

(which was not certified by peer review) is the author/funder, who has granted bioRxiv a license to display the preprint in perpetuity. It is made available under aCC-BY 4.0 International license.

similar levels of Nck and induced comparable numbers of actin tails (Figure 7 - supplement $1 \mathrm{~A}$ and $\mathrm{B})$. Nevertheless, the $\mathrm{A} 36 \mathrm{G}-\mathrm{N}$ and G-G-N viruses induced the formation of equally short actin tails (Figure 7B). In contrast, the actin tails formed by the A36 G-N-G virus are noticeably longer. A similar trend was also observed for virus speed and spread (Figure 7C,

295 D). Strikingly, the G-N-G and N-G viruses recruit similar levels of N-WASP, which are $~ 2-$ fold greater than the G-G-N and G-N viruses (Figure 7E). They also recruit significantly more GFP-Grb2 (Figure 7-supplement 1C). Grb2 is not essential for Vaccinia actin tail formation but its binding position relative to Nck clearly influences the level of N-WASP recruitment. This has a profound influence on the organization and output of the signalling network 300 stimulated by phosphorylation of $A 36$.

\section{DISCUSSION}

The pTyr motifs in Vaccinia A36 engage the SH2-SH3 adaptors Nck and Grb2, which play essential roles in many different cellular signalling cascades. For example, Grb2 directly 305 binds receptors EGFR and Ras via its SH2 domain, while the SH2 domain of Nck binds PDGFR and ephrinb1 receptors among others (Bong et al., 2003; Cowan and Henkemeyer, 2018; Lettau et al., 2009; Nishimura et al., 2005; Pramatarova et al., 2003). These adaptors also participate in signalling networks that can undergo phase transitions, including those assembled by the membrane proteins LAT and nephrin in T-cell activation and kidney

310 podocytes respectively (Case et al., 2019; Ditlev et al., 2019; Kim et al., 2019; Pak et al., 2016; Su et al., 2016). LAT engages Grb2 for its function while nephrin relies on Nck. In the case of Vaccinia, the recruitment of Nck and Grb2 at the plasma membrane leads to the recruitment of a signalling network that induces the formation of Arp2/3-dependent actin polymerization that acts to enhance the spread of viral infection (Frischknecht et al., 1999;

315 Ward and Moss, 2004). The virus provides a model system to dissect this signalling network in a true physiological context as the output is robust, can be easily quantified and manipulated using recombinant viruses and different cell lines (Scaplehorn et al., 2002; Weisswange et al., 2009). 
320 We have taken advantage of this model to address whether the relative positioning of pTyr motifs plays a role in the output of the system, as this is an unexplored aspect of pTyr networks. To tackle this question, we used a truncated variant of $A 36$, which still recruits both Nck and Grb2 to induce robust actin polymerization. In addition, we also generated a recombinant virus expressing the cytoplasmic C-terminus of the unrelated integral 325 membrane p14 from Orthoreovirus. p14 promotes N-WASP and Arp2/3 dependent cell fusion during Orthoreovirus infection by interacting with Grb2 using a pTyr116 motif located in its short cytoplasmic tail (Chan et al., 2020). We chose p14 as Scansite and ELM predictions suggested that it may also contain a Nck binding site 20 residues upstream of the Grb2 binding site (Kumar et al., 2019; Obenauer et al., 2003). Using these two models,

330 we have uncovered that the relative position of the Nck and Grb2 pTyr binding motifs has a profound impact on the output of the signalling network. In the wild type situation, the Nck binding site (pTyr112 and pTyr96 in A36 and p14 respectively) plays the dominant role in promoting actin polymerization, while Grb2 plays a supporting role. This is consistent with previous in vitro observations demonstrating that Grb2 is significantly less efficient than Nck

335 at promoting actin polymerization via N-WASP and Arp2/3 (Carlier et al., 2000; Okrut et al., 2015). Swapping the position of the two adaptor binding sites severely impairs actin-based motility and spread of the virus. The impairment seen in the swapped configuration of A36 correlates with reduced N-WASP accumulation at the virus, even though the levels of Nck remain the same. The levels of Grb2 are also reduced, even though Tyr132 is still 340 phosphorylated. By introducing a second Grb2 site N or C-terminal to Nck when it is in the "swapped" configuration, we found that the relative position of Grb2 has a dramatic impact on the system regardless of the level of Nck, which remains constant in our different recombinant viruses. The output of the network clearly does not merely depend on the level of Nck recruitment. This suggests that Grb2 places constraints on the organization of

345 the network that limit or impede the ability of Nck to bind N-WASP and activate the Arp2/3 complex to promote actin polymerization. 
So why does the position of Grb2 recruitment relative to that of Nck matter? Nck and Grb2 are multivalent adaptors that can interact with N-WASP to activate Arp2/3. Grb2 has two

350 SH3 domains that bind N-WASP while the three SH3 domains of Nck engage with WIP and N-WASP (Carlier et al., 2000; Donnelly et al., 2013; Rivera et al., 2004). In addition, the interdomain linker of Nck also contributes to N-WASP activation (Banjade et al., 2015; Bywaters and Rivera, 2021; Okrut et al., 2015). One would envisage that these different interactions offer the possibility of activating N-WASP via a number of different routes. This

355 notion would also be consistent with the concept of phase transition, which is dependent on stochastic multivalent interactions (Fuxreiter and Vendruscolo, 2021; Lyon et al., 2021). However, our observations clearly demonstrate that there is a preferred configuration or directionality to achieve the optimal network output. This implies that the network has underlying wiring principles.

Our finding that optimal signalling outputs are only achieved with specific pTyr motif configurations has important implications for membrane-associated complexes in the field of cellular condensates as well as in modular signalling. Recent evidence points to organizational principles that could govern the function of other cellular condensates such

365 as $\mathrm{P}$ granules, stress granules and puncta formed by the FUS (fused in sarcoma) protein (Bienz, 2020; Folkmann et al., 2021; Jain et al., 2016; Kato and McKnight, 2017; Kato et al., 2012). But as of yet, no rules have been elucidated for membrane signalling. Our observations are not predicted by a phase transition-based model, where high conformational entropy and multiple binding configurations are assumed to be available

370 (Fuxreiter and Vendruscolo, 2021; Lyon et al., 2021). This is thought to be the case particularly when signalling motifs are present in disordered regions of proteins. Disordered proteins, which constitute $40 \%$ of the human proteome, are rich in short linear motifs (SLiMs) (Tompa et al., 2014; Wright and Dyson, 2014). Due to their ubiquity and modularity, networks assembled via SLiMs in unstructured peptides are of immense interest to 375 biologists building synthetic signalling systems (Lim, 2010). In synthetic networks, the optimal organisation of globular domains is recognized to influence functionality, for 
example in the construction of chimeric antigen receptors (Finney et al., 1998). However, the relative position of SLiMs within a complex network has never been considered to play a role. As viral proteins are enriched in disordered regions with short host-mimicking motifs

380 (Davey et al., 2011; Uversky, 2019), they offer unique tools to explore the importance of SLiMs positioning on signalling output, given the implications for signalling networks undergoing phase transition. Our observations also demonstrate that Vaccinia provides an excellent model platform to dissect additional signalling networks (physiological or synthetic) activated by Src and Abl family kinases.

\section{FIGURE LEGENDS}

\section{Figure 1: A36 interactions and the Vaccinia signalling network.}

A schematic showing the Vaccinia virus protein A36 and its known interactors. Kinesin-1 that drives microtubule-based transport of virions to the plasma membrane binds the 390 WD/WE motifs. Nck and Grb2 bind Y112 and Y132 respectively when they are phosphorylated by Src and Abl family kinases. Nck and Grb2 interact with WIP and N-WASP via their SH3 domains, which results in the activation of the Arp2/3 complex and stimulation of actin polymerization. The region deleted in A36 after residue 139 (red triangle) to abolish the involvement of the RhoGEF intersectin and its binding partners clathrin and Cdc42 is 395 shown in grey.

Figure 1 - supplement 1: pTyr motifs are found in disordered regions.

A. Shows a graph predicting the intrinsic disorder of human EGFR (https://iupred2a.elte.hu/). The positions of key phosphotyrosine residues and the 400 transmembrane domain (TM) are indicated. B. Clustal sequence alignment of the Cterminus of EGFR from the indicated species. Positions of the conserved Grb2 and Shc1 adaptor binding sites are shown in pink and blue respectively. C. Shows the predicted intrinsic disorder of Vaccinia A36 and Orthoreovirus p14 together with the positions of key phosphotyrosine residues involved in recruiting Nck and Grb2 and the transmembrane 405 domain (TM). 
Figure 2: Phosphotyrosine motif position impacts actin-based motility and viral spread.

A. C-terminal amino acid sequence of A36 in recombinant viruses showing the position of phosphotyrosine motifs in their wild type (A36 N-G) and swapped (A36 G-N) configurations.

410 B. Representative immunofluorescence images of actin tails in HeLa cells infected with the indicated virus at 8 hours post-infection. Actin is stained with phalloidin, and extra-cellular virus particles attached to plasma membrane are labelled using an antibody against the viral protein B5. Scale bar $=3 \mu \mathrm{m}$. The graphs show quantification of number of extracellular virus particles inducing actin tails and their length. A total of 270 actin tails were measured

415 in three independent experiments. C. Temporal colour-coded representation of time-lapse movies tracking the motility of the indicated RFP-A3-labelled virus over 50 seconds at 8 hours post infection (Supplemental Movie 1). Images were recorded every second and the position of virus particles at frame 1 (yellow triangles) and frame 50 (red triangles) are indicated. Scale bar $=3 \mu \mathrm{m}$. The graph shows quantification of virus speed over 50 seconds.

420 A total of 82 virus particles were tracked in three independent experiments. D. Representative images and quantification of plaque diameter produced by the indicated virus in confluent BS-C-1 cells 72 hours post-infection. 64 plaques were measured in three independent experiments. Scale bar $=3 \mathrm{~mm}$. All error bars represent S.D and the distribution of the data from each experiment is shown using a "SuperPlot". Welch's t test 425 was used to determine statistical significance; $n s, p>0.05 ; * p \leq 0.05 ; * * p \leq 0.01$.

Figure 2 - supplement 1: Quantification of the number of virus inducing actin tails along with their length.

A. Left - Amino acid sequences of the indicated truncated A36 recombinants where either 430 one or both phosphotyrosine motifs (orange for Nck and purple for Grb2) are disrupted with a Tyr (Y) to Phe (F) point mutation. Right - Quantification of the number of extracellular virus inducing actin tails together with their length. B. C-terminal amino acid sequences of truncated A36 recombinants with wildtype or swapped Nck binding sites but deficient in Grb2 recruitment (Phe substitution) together with quantification of the number of 
435 extracellular virus inducing actin tails together with their length. The same A36 N-X data is shown in A and $\mathbf{B}$. In both cases, 240 actin tails were measured in three independent experiments, except in the A36 X-G mutant where very few actin tails were made. All error bars represent S.D. and the distribution of the data from each experiment is shown using a "SuperPlot". Dunnett's multiple comparison's test was used to determine statistical $440 \quad$ significance; $n s, p>0.05 ; * * p \leq 0.01 ; * * * * p \leq 0.0001$.

\section{Supplemental Movie 1: Phosphotyrosine motif position impacts actin-based motility of} Vaccinia virus. HeLa cells stably expressing LifeAct-iRFP670 (green) were infected with either the A36 N-G or A36 G-N virus labelled with RFP-A3 (magenta) for 8 hours. Images

445 were taken every second. Video plays at 5 frames per second. The RFP-A3 signal was used to generate the temporal colour-coded representation in Figure $2 \mathrm{C}$. The time in seconds is indicated, and the scale bar $=3 \mu \mathrm{m}$.

\section{Figure 3: Generating and validating an A36-p14 hybrid that can polymerise actin.}

450 A. Schematic showing a hybrid construct (referred to as p14 N-G) comprising the first 105 residues of A36 and the C-terminal residues 79-125 of Orthoreovirus p14 protein. Positions of the predicted Nck-binding sites at Tyr96 and Tyr100, and the previously established Grb2binding site at Tyr116 are shown together with their respective sequences. B. Representative immunofluorescence images of actin tails in HeLa cells infected with 455 Vaccinia virus lacking the A36 gene and transiently expressing the indicated constructs under the A36 promoter at 8 hours post-infection. Actin is stained with phalloidin, and extra-cellular virus particles attached to plasma membrane are labelled using an anti-B5 antibody. Scale bar $=3 \mu \mathrm{m}$. C. Representative immunofluorescence images of N-WASP null or parental mouse embryonic fibroblast cells infected with Vaccinia virus lacking the A36

460 gene and transiently expressing the p14 N-G construct under the A36 promoter at 16 hours post-infection. Actin is stained with phalloidin, and extra-cellular virus particles are labelled using an anti-B5 antibody. Scale bar $=3 \mu \mathrm{m}$. The graph shows quantification of actin tail number per extracellular virus particle. Error bars represent S.D. from three independent 
experiments. Welch's t test was used to determine statistical significance; * $p \leq 0.05$. D and

465 E. Quantification of the number of extracellular virus inducing actin tails together with their length in HeLa cells infected with Vaccinia virus lacking the A36 gene and transiently expressing p14 N-G constructs under the A36 promoter with indicated Tyr to Phe mutations, at 8 hours post-infection. 125 actin tails were measured in three independent experiments, except in mutants Y96F and Y116F where fewer actin tails were made. All error bars 470 represent S.D and the distribution of the data from each experiment is shown using a "SuperPlot". Dunnett's multiple comparison's test (for panel D) and Welch's t test (for panel E) were used to determine statistical significance; $n s, p>0.05 ; * * p \leq 0.01 ; * * * p \leq 0.001$. F. Immunoblot analysis of peptide pulldowns showing that endogenous Nck from HeLa cell lysates binds to phosphopeptides corresponding to Tyr96 from the Orthoreovirus p14 and

475 Tyr112 of the Vaccinia A36 but not to their unphosphorylated counterparts.

Figure 4: Phosphotyrosine motif position in a A36-p14 hybrid protein impacts actin polymerisation.

A. Representative images showing the recruitment of Nck, WIP, Grb2 and N-WASP to actin 480 tails in HeLa cells infected with a recombinant virus expressing the p14 N-G construct at the A36 locus at 8 hours post-infection. Endogenous Nck, N-WASP and WIP were detected with antibodies and actin is labelled with phalloidin. To ascertain Grb2 localisation, infected HeLa cells stably expressing GFP-Grb2 and transiently expressing LifeAct iRFP were imaged live. Scale bar $=2 \mu \mathrm{m}$. B. C-terminal amino acid sequence of the A36 -p14 hybrid in recombinant

485 viruses showing the positions of phosphotyrosine motifs in their wild-type (p14 N-G) and swapped (p14 G-N) configurations. C. Representative immunofluorescence images of actin tails in HeLa cells infected with the indicated virus at 8 hours post-infection. Actin is stained with phalloidin, and extra-cellular virus particles are using an anti-B5 antibody. Scale bar $=$ $3 \mu \mathrm{m}$. The graphs show quantification of number of extracellular virus particles inducing actin tails and their length. 336 actin tails were measured in four independent experiments. D. Temporal colour-coded representation of time-lapse movies tracking the motility of the indicated RFP-A3-labelled virus over 50 seconds at 8 hours post infection (Supplemental 
Movie 2). Images were recorded every second and the position of virus particles at frame 1 (yellow triangles) and frame 50 (red triangles) are indicated. Scale bar $=3 \mu \mathrm{m}$. The graph shows quantification of virus speed over 50 seconds. 75 virus particles were tracked in three independent experiments. E. Representative images and quantification of plaque diameter produced by the indicated virus in confluent BS-C-1 cells 72 hours post-infection. 72 plaques were measured in three independent experiments. Scale bar $=3 \mathrm{~mm}$. All error bars represent S.D and the distribution of the data from each experiment is shown using a "SuperPlot". Welch's t test was used to determine statistical significance; ns, p >0.05; * p $\leq 0.05 ; * * p \leq 0.01$.

\section{Supplemental Movie 2: Phosphotyrosine motif position impacts actin-based motility} driven by $\mathbf{p} 14$ N-G virus. HeLa cells stably expressing LifeAct-iRFP670 (green) were infected 505 with either the p14 N-G or p14 G-N virus labelled with RFP-A3 (magenta) for 8 hours. Images were taken every second. Video plays at 5 frames per second. The RFP-A3 signal was used to generate the temporal colour-coded representation in Figure 4D. The time in seconds is indicated, and the scale bar $=3 \mu \mathrm{m}$.

510 Figure 4 - supplement 1: Validation of stable cell lines by immunoblot.

Immunoblot analyses of total cell lysates from HeLa cell lines stably expressing GFP-Nck, GFP-Grb2 or GFP-N-WASP with the indicated antibodies. The green and magenta triangles indicate the GFP-tagged and endogenous proteins respectively. ${ }^{* *}$ denotes non-specific bands.

Figure 5: N-WASP recruitment is impaired when Grb2 binding is repositioned in A36.

A. Representative images showing the indicated GFP-tagged protein recruitment to RFP-A3 labelled virus particles in live HeLa cells infected with the indicated viruses at 8 hours postinfection. Scale bar $=2 \mu \mathrm{m}$. The graphs show quantification of GFP:RFP-A3 fluorescence 520 intensity ratio. Intensity of 90 virus particles was measured in three independent experiments. B. Left - The graph shows quantification of GFP-Nck intensity at extracellular 
virus particles in mouse embryonic fibroblasts (MEFs) lacking both Nck1 and Nck2 and stably expressing GFP-Nck1 at 16 hours post-infection. Intensity of 1200 virus particles was measured in three independent experiments. Right - The graph shows quantification of GFP-N-WASP:RFP-A3 fluorescence intensity ratio on virus particles in live N-WASP-/- MEFs stably expressing GFP-N-WASP infected with the indicated viruses at 16 hours postinfection. Intensity of 75 virus particles was measured in three independent experiments. C. The graphs show quantification of GFP:RFP-A3 fluorescence intensity ratio on virus particles in live HeLa cells stably expressing the indicated GFP-tagged protein infected with

530 the $A 36 \mathrm{~N}-\mathrm{G}, \mathrm{G}-\mathrm{N}$ or N-X viruses at 8 hours post-infection. Intensity of 90 virus particles was measured in three independent experiments. All error bars represent S.D and the distribution of the data from each experiment is shown using a "SuperPlot". Dunnett's multiple comparison's test (for panel C) or Welch's t test (remaining panels) were used to determine statistical significance; $n s, p>0.05 ;{ }^{*} p \leq 0.05 ; * * p \leq 0.01$.

Figure 5 - supplement 1: Fluorescence intensity measurements of Vaccinia recombinants.

A. The graphs show quantification of RFP-A3 intensity on virus particles in different recombinants (left) and HeLa cell lines (right) measured in live cells at 8 hours postinfection. These datasets correspond to Figure 5A. Intensity of 90 virus particles was 540 measured in three independent experiments. B. Left - A schematic showing the A36 variant expressed in each recombinant virus. The Nck-binding motif is indicated in orange, the Grb2-binding motif in purple and tgGFP2 in green. Middle - Representative images of tgGFP2 and RFP-A3 labeled virus particles in live HeLa cells stably expressing LifeAct iRFP infected with the indicated viruses recorded 8 hours post-infection. All virus particles are

545 marked with an RFP tag fused to a viral core protein A3. Scale bar $=2 \mu \mathrm{m}$. Right - The graph shows quantification tgGFP2:RFP fluorescence intensity ratios at the tip of actin tails. Intensity of 95 virus particles was measured in three independent experiments. C. Representative images showing GFP-WIP recruitment to RFP-A3 labelled virus particles in live HeLa cells infected with the indicated viruses recorded 8 hours post-infection. Scale bar $550=2 \mu \mathrm{m}$. The graph shows quantification of GFP-WIP:RFP-A3 fluorescence intensity ratio. 
Intensity of 90 virus particles was measured in three independent experiments. All error bars represent S.D and the distribution of the data from each experiment is shown using a "SuperPlot". Dunnett's multiple comparison's test (for panel A right) or Welch's t test (remaining panels) were used to determine statistical significance; $n s, p>0.05 ; * * p \leq 0.01$.

Figure 5 - supplement 2: Verification of stable cell lines by immunoblot.

Immunoblot analyses of total cell lysates from N-WASP or Nck null MEFs with or without stable expression of their respective GFP-tagged version together with their parental wildtype cells. Immunoblot analyses was performed with the indicated antibodies. The

560 green and magenta triangles indicate the GFP-tagged and endogenous proteins respectively. ${ }^{* *}$ denotes non-specific bands.

Figure 6: The Grb2-binding site in A36 is phosphorylated when motif positions are changed.

565 A. Representative immunofluorescence images of A36 pY132 antibody labelling of indicated virus inducing actin tails in HeLa cells at 8 hours post-infection. Actin is stained with phalloidin. A36 N-X is a virus where the A36 Grb2-binding site is disrupted with by Tyr to Phe point mutation. The white arrowheads indicate virus position. Scale bar $=1 \mu \mathrm{m}$. The graph shows quantification of background-subtracted antibody intensity at the tip of actin

570 tails. B. Quantification of background-subtracted A36 pY132 antibody intensity in HeLa cells infected with the A36 N-G virus and treated with indicated siRNA. The $p$ value here is 0.071 . On the right a representative immunoblot from one of three experimental repeats is shown. Vinculin levels were used as a loading control. Intensity of 85 virus particles was measured in three independent experiments. All error bars represent S.D. and the distribution of the 575 data from each experiment is shown using a "SuperPlot". Tukey's multiple comparison's test (for panel A) and Welch's t test (for panel B) were used to determine statistical significance; $n s, p>0.05 ; * p \leq 0.05 ; * * p \leq 0.01$. 
Figure 7: Signalling output can be improved by adding a new Grb2 binding site, but only 580 in a position-dependent fashion.

A. C-terminal amino acid sequence of A36 in recombinant viruses showing the position of phosphotyrosine motifs in wild type (A36 N-G) and swapped (A36 G-N) configurations and with a new Grb2-binding site C-terminal (G-N-G) or N-terminal (G-G-N) to the swapped configuration. B. Representative immunofluorescence images of actin tails in HeLa cells

585 infected with the indicated virus at 8 hours post-infection. Actin is stained with phalloidin, and extra-cellular virus particles are labelled using an anti-B5 antibody. Scale bar $=5 \mu \mathrm{m}$. The graph shows quantification of actin tail length. 195 actin tails were measured in three independent experiments. C. The graph shows quantification of virus speed from time-lapse movies tracking the motility of the indicated RFP-A3-labelled virus over 50 seconds at 8

590 hours post infection. 90 virus particles were tracked in three independent experiments. D. Representative images and quantification of plaque diameter produced by the indicated virus in confluent BS-C-1 cells 72 hours post-infection. 60 plaques were measured in three independent experiments. Scale bar $=2 \mathrm{~mm}$. E. Representative images showing GFP-NWASP and RFP-A3 intensity on virus particles in live HeLa cells infected with the indicated

595 viruses recorded 8 hours post-infection. Scale bar $=4 \mu \mathrm{m}$. GFP N-WASP intensity data for A36 N-G and G-N viruses is the same as in Figure 5C. The graph shows quantification of GFPN-WASP:RFP-A3 fluorescence intensity ratio. Intensity of 90 virus particles was measured in three independent experiments. All error bars represent S.D and the distribution of the data from each experiment is shown using a "SuperPlot". Tukey's multiple comparison test was 600 used to determine statistical significance; $n s, p>0.05 ;{ }^{*} p \leq 0.05 ; * * p \leq 0.01 ; * * p \leq 0.001$.

Figure 7 - supplement 1: Quantification of the number of virus inducing actin tails and GFP-Nck recruitment in A36 variants with an extra Grb2-binding site.

A. Quantification of number of extracellular virus particles inducing actin tails in the 605 indicated viruses. B. Quantification of the GFP-Nck:RFP-A3 fluorescence intensity ratio of virus particles in live HeLa cells infected with the indicated viruses at 8 hours post-infection. The data for A36 N-G and G-N viruses is the same as in Figure 5C. Intensity of 85 virus 
particles was measured in three independent experiments. C. Representative images showing GFP-Grb2 and RFP-A3 intensity on virus particles in live HeLa cells infected with the

610 indicated viruses recorded 8 hours post-infection. The insets show a $2 x$ magnification of the yellow boxed regions. Scale bar $=16 \mu \mathrm{m}$. The graph shows quantification of GFP-Grb2:RFPA3 fluorescence intensity ratio. Intensity of 90 virus particles was measured in three independent experiments. All error bars represent S.D. and the distribution of the data from each experiment is shown using a "SuperPlot". Tukey's multiple comparison test was used

615 to determine statistical significance; $n s, p>0.05 ; * * p \leq 0.01 ; * * * p \leq 0.001$.

\section{METHODS}

\section{Expression constructs and targeting vectors}

The expression vectors pE/L-LifeAct-iRFP670 (Galloni et al., 2021), pLVX-GFP-N-WASP

620 (Donnelly et al., 2013) and pBS SKII RFP-A3L targeting vector (Weisswange et al., 2009) were previously made in the Way lab. The lentiviral expression construct pLVX-GFP-Nck was generated by sub-cloning the Nck1 coding sequence (Donnelly et al., 2013) into Notl/EcoRI sites of a pLVX-N-term-GFP parent vector (Abella et al., 2016). All other expression constructs generated for this study were made using Gibson Assembly (New England

625 Biolabs) according to manufacturer's instructions. Desired amino acid substitutions were introduced by whole-plasmid mutagenesis using complementary mutagenic primers. All primers used in cloning are listed in Table 1. The lentiviral expression construct pLVX-GFPGrb2 was generated by cloning a GFP-Grb2 (Weisswange et al., 2009) fragment into the Xhol/EcoRI sites of a pLVX parent vector (Abella et al., 2016). The A36R-targeting vector was 630 generated by amplifying a fragment containing the A36R gene including $325 \mathrm{bp}$ upstream and downstream sequences from the WR strain of Vaccinia virus genomic DNA and cloning into the Notl/HindIII sites of pBS SKII. This vector was modified to generate desired A36 truncations and variants. The tagGFP2 coding sequence used in the A36 N-G and A36-G-N fusion constructs was amplified from a plasmid provided by David Drubin (UC Berkeley)

635 (Akamatsu et al., 2020). The A36-p14 chimeric construct was obtained as a synthetic gene (Invitrogen; Geneart) and cloned into the A36R-targeting vector using Spel/BsrGI sites in 
the sequences flanking the A36R coding region. SnapGene software (from Insightful Science; available at snapgene.com) was used to plan and visualise cloning strategies, and to analyse sequencing results.

640

Table 1. Primers

\begin{tabular}{|c|c|c|}
\hline No. & Sequence & Construct(s) generated \\
\hline AB007 & ACACATTTtCGATAGTGTTGCTGG & A36 X-G \\
\hline AB008 & GCAACACTATCGaAAATGTGTTCTG & A36 X-G \\
\hline AB009 & CAGACTATTTtTCAGAACACTACAGTAGTA & $\begin{array}{l}\text { A36 N-X, A36 X-N, A36 X- } \\
X\end{array}$ \\
\hline AB010 & CTGTAGTGTTCTGAaAAATAGTCTGT & $\begin{array}{l}\text { A36 N-X, A36 X-N, A36 X- } \\
X\end{array}$ \\
\hline AB105 & TCAGCCAGCACGAGTtCGAGGACCCCTACGAGCCCCCCAG & p14 N-G (Y96F) \\
\hline AB106 & CTGGGGGGCTCGTAGGGGTCCTCGaACTCGTGCTGGCTGA & p14 N-G (Y96F) \\
\hline AB107 & ACGAGTACGAGGACCCCTtCGAGCCCCCCAGCAGGAGGAA & p14 N-G (Y100F) \\
\hline AB108 & TTCCTCCTGCTGGGGGGCTCGaAGGGGTCCTCGTACTCGT & p14 N-G (Y100F) \\
\hline AB109 & CTACAGCACCTtCGTGAACATCGACAACGTGAGCGCCATC & $\begin{array}{l}\text { p14 N-G (Y116F) and p14 } \\
\text { N-G (Y96,116F) }\end{array}$ \\
\hline AB110 & GCGCTCACGTTGTCGATGTTCACGaAGGTGCTGTAGGGG & $\begin{array}{l}\text { p14 N-G (Y116F) and p14 } \\
\text { N-G (Y96,116F) }\end{array}$ \\
\hline AB040 & TACCGGACTCAGATCtcgagATGAGCAAGGGCGAGGAGC & pLVX-GFP-Grb2 \\
\hline AB057 & CGTCGACTGCAGAATTCttaCTAGACGTTCCGGTTCACGGGGG & pLVX-GFP-Grb2 \\
\hline AB051 & CACCGCGGTGGCGGCCGCtcatcatagcat & $\begin{array}{l}\text { A36 N-G, A36 G-N, A36 G- } \\
\text { N-G, A36 G-G-N }\end{array}$ \\
\hline AB052 & GGTCGACGGTATCGATAAGCTTtatctatagagataacac & $\begin{array}{l}\text { A36 N-G, A36 G-N, A36 G- } \\
\text { N-G, A36 G-G-N, p14-N- } \\
\text { G, p14 G-N }\end{array}$ \\
\hline AB053 & tgattagtttcctttttataaaattgAAGTAATATTTAGT & A36 N-G, A36 G-N \\
\hline AB054 & ataaaaaggaaactaatcaCGTGCTTCCAGCAACACTAT & A36 G-N \\
\hline AB055 & ataaaaaggaaactaatcaAATTACTACTGTAGTGTTCTG & A36 N-G \\
\hline AB087 & TATTTATCAGAACACTACAGTAGTAATTtgattagtttccttttta & A36 G-N-G \\
\hline AB088 & $\begin{array}{l}\text { AGTGTTCTGATAAATAGTCTGTTCATTACGATCATTATTTATTA } \\
\text { GCAGCGTGCTTCCAGCAACA }\end{array}$ & A36 G-N-G \\
\hline AB089 & CTAATAAATAATGATCGTAATGAACAGACTATTTATCAGAAC & A36 G-G-N \\
\hline AB090 & $\begin{array}{l}\text { ATTACGATCATTATTTATTAGCAGAATTACTACTGTAGTGTTCT } \\
\text { GATAAAT }\end{array}$ & A36 G-G-N \\
\hline
\end{tabular}




\begin{tabular}{|c|c|c|}
\hline AB096 & AAACAATAAATATTGAACTAGTAGTACGTATattgagc & $\begin{array}{l}\text { A36 N-G-tgGFP2, A36 G- } \\
\text { N-tgGFP2, p14 N-G, p14 } \\
\text { G-N }\end{array}$ \\
\hline AB097 & $\begin{array}{l}\text { TCCGGTGGCGACCGGTGGATCCGACCCCGACCCAATTACTACT } \\
\text { GTAGTGTTCTGATAA }\end{array}$ & A36 N-G-tgGFP2 \\
\hline AB098 & $\begin{array}{l}\text { TCCGGTGGCGACCGGTGGATCCGACCCCGACCCCGTGCTTCC } \\
\text { AGCAACACTATCGTAA }\end{array}$ & A36 G-N-tgGFP2 \\
\hline AB121 & AGGAACAGCTACAGGCTGAG & p14 N-G, p14 G-N \\
\hline AB122 & CTCAGCCTGTAGCTGTTCCTCGCCATGACATTGGATT & p14 N-G, p14 G-N \\
\hline
\end{tabular}

\section{Cell lines}

645 All cell lines were maintained in minimal essential medium (MEM) supplemented with 10\% FBS, $100 \mathrm{U} / \mathrm{ml}$ penicillin, and $100 \mu \mathrm{g} / \mathrm{ml}$ streptomycin at $37^{\circ} \mathrm{C}$ and $5 \% \mathrm{CO}_{2}$. HeLa cell lines stably expressing LifeAct-iRFP670 (Snetkov et al., 2016) and GFP-WIP (Weisswange et al., 2009) were previously generated in the Way lab. Nck -/- MEFs (Bladt et al., 2003) and NWASP-/-MEFs (Snapper et al., 2001) were provided by the late Tony Pawson (Samuel

650 Lunenfeld Research Institute, Toronto, Canada) and Scott Snapper (Harvard Medical School, Boston, MA) respectively. For this study, lentiviral expression vectors were used to stably express GFP-Nck in HeLa cells and Nck-/- MEFs, GFP-N-WASP in HeLa cells and N-WASP-/MEFs, and GFP-Grb2 in HeLa cells. All cell lines were generated using the lentivirus Trono group second generation packaging system (Addgene) and selected using puromycin 655 resistance $(1 \mu \mathrm{g} / \mathrm{ml})$ as previously described (Abella et al., 2016). Expression of the relevant fusion proteins was confirmed by live imaging and immunoblot analysis (Suppl. Figure 5). The following primary antibodies were used: anti-Nck (BD transduction; 1:1000), antivinculin (Sigma \#V4505; 1:2000), anti-Grb2 (BD Transduction \#610112, 1:3000), anti-NWASP (Cell Signalling \#4848S; 1:1000), anti-GFP (3E1 custom made by Cancer Research UK; 660 1:1000). HRP-conjugated secondary antibodies were purchased from The Jackson Laboratory. 


\section{Viral plaque assays}

665 Plaque assays were performed in confluent BS-C-1 cell monolayers. Cells were infected with the relevant Vaccinia virus at a multiplicity of infection (MOI) $=0.1$ in serum-free MEM for one hour. The inoculum was replaced with a semi-solid overlay consisting of a 1:1 mix of MEM and 2\% carboxymethyl cellulose. Cells were fixed with 3\% formaldehyde at 72 hours post-infection and subsequently visualized with crystal violet cell stain as previously

670 described (Humphries et al., 2012). To determine plaque size, the diameter of wellseparated plaques was measured using the Fiji line tool (Schindelin et al., 2012).

\section{Construction of recombinant Vaccinia viruses}

In this study, recombinant Vaccinia viruses in the WR background were isolated by selecting

675 viral plaques based on their size or by introduction of a fluorescently-tagged viral protein as described previously (Snetkov et al., 2016; Weisswange et al., 2009). The former strategy was used to generate recombinants where A36 variants were introduced at the endogenous locus by rescuing plaque size in the $\mathrm{WR}-\Delta \mathrm{A} 36 \mathrm{R}$ virus that makes very small plaques (Parkinson and Smith, 1994; Ward et al., 2003). To introduce relevant constructs into the 680 A36 genomic locus, HeLa cells infected with $\mathrm{WR}-\triangle \mathrm{A} 36 \mathrm{R}$ at $\mathrm{MOI}=0.05$ were transfected with the appropriate pBS SKII A36R-targeting vectors using Lipofectamine2000 (Invitrogen) as described by the manufacturer. In the case of the p14 N-G virus, a PCR fragment containing the desired construct flanked by recombination arms was used for transfection. When all cells displayed cytopathic effect at 48-72 hours post-infection, they were lysed, and serial

685 dilutions of the lysates were used to infect confluent BS-C-1 cell monolayers in a plaque assay (see above). Plaques were revealed by neutral red staining and recombinants were identified and picked based on increased plaque size. Plaque lysates were used to infect fresh BS-C-1 cell monolayers over at least three rounds of plaque purification. To isolate A36 N-G-tgGFP2 and A36 G-N-tgGFP2 viruses, in addition to size, plaque fluorescence was used to identify recombinants. To generate recombinants where the viral core was fluorescently labelled with RFP, HeLa cells infected with the relevant parent virus were transfected with the pBS SKII RFP-A3-targeting vector (Weisswange et al., 2009). 
Recombinant viruses were isolated based on RFP fluorescence over at least three rounds of plaque purification. In all cases, successful recombination at the correct locus, loss of the parent variant and virus purity were verified by PCR and sequencing. All recombinant viruses were purified through a sucrose cushion before use and storage.

\section{Vaccinia virus infection for imaging}

For live and fixed cell imaging, cells were infected with the relevant Vaccinia virus recombinant in serum-free $\mathrm{MEM}$ at $\mathrm{MOI}=1$. After one hour at $37^{\circ} \mathrm{C}$, the serum-free $\mathrm{MEM}$ was removed and replaced with complete MEM. Cells were incubated at $37^{\circ} \mathrm{C}$ until further processing.

\section{Transient transfection and siRNA}

705 Transient transfection of A36-p14 hybrid constructs and the pE/L-LifeAct-iRFP670 expression in Vaccinia-infected cells was done using FUGENE (Promega) as described by the manufacturer. To transiently express the A36-p14 chimera and its variants (Figure 3B to E), expression vectors containing the relevant construct under the control of the A36 promoter were transfected into cells one hour after infection with the WR- $\Delta A 36$ virus (Parkinson and

710 Smith, 1994). To visualize actin structures in live HeLa cells stably expressing GFP-Grb2 (Figure 4A), cells were transfected with pE/L-LifeAct-iRFP670 (Galloni et al., 2021) one hour after infection with p14 N-G virus. For knockdown experiments, HeLa cells were transfected with siRNA as previously described (Abella et al., 2016). Cells were infected with Vaccinia virus 72 hours after siRNA transfection, and samples from each siRNA condition were kept

715 for immunoblot analysis. The following siRNAs were used: AllStars (Qiagen; SI03650318), Grb2-targeting oligos GARA and CGAAGAAUGUGAUCAGAACUU. The following primary antibodies were used in immunoblots: anti-vinculin (Sigma \#V4505; 1:2000), anti-Grb2 (BD Transduction \#610112, 1:3000). HRP-conjugated secondary antibodies were purchased from The Jackson 720 Laboratory. 


\section{Immunofluorescence}

At 8 hours (HeLa) or 16 hours (MEFs) post-infection, cells were fixed with $4 \%$ paraformaldehyde in PBS for 10 min, blocked in cytoskeletal buffer (1 mM MES, 15 mM $725 \mathrm{NaCl}, 0.5 \mathrm{mM}$ EGTA, $0.5 \mathrm{mM} \mathrm{MgCl}_{2}$, and $0.5 \mathrm{mM}$ glucose, $\mathrm{pH}$ 6.1) containing 2\% (vol/vol) fetal calf serum and 1\% (wt/vol) BSA for $30 \mathrm{~min}$, and then permeabilized with $0.1 \%$ TritonX/PBS for 5 min. To visualize cell-associated enveloped virions (CEV), cells were stained with, with a monoclonal antibody against B5 (19C2, rat, 1:1000; (Hiller and Weber, 1985)) followed by an Alexa Fluor 647 anti-rat secondary antibody (Invitrogen; 1:1000 in PBS) prior

730 to permeabilization of the cells with detergent. Other primary antibodies used were antiNck (Millipore \#06-288; 1:100), anti-WIP (1:100; (Moreau et al., 2000)), and anti-N-WASP (Cell Signalling \#4848S; 1:100) followed by Alexa Fluor 488 conjugated secondary antibodies (Invitrogen; 1:1000 in PBS). Actin tails were labeled with Alexa Fluor 488, Alexa Fluor 568 or Alexa Fluor 647 phalloidin (Invitrogen; 1:500). Coverslips were mounted on glass slides using

735 Mowiol (Sigma). Coverslips were imaged on a Zeiss Axioplan2 microscope equipped with a 63x/1.4 NA Plan-Achromat objective and a Photometrics Cool Snap HQ cooled chargecoupled device camera. The microscope was controlled with MetaMorph 7.8.13.0 software. To measure the levels of pY132 at the virus (Figure 6) coverslips were fixed with $4 \%$ paraformaldehyde containing $0.1 \%$ Triton-X prior to staining with an antibody against the

740 A36 phosphotyrosine 132 site (1:100, (Newsome et al., 2004)). Mounted coverslips were imaged on an Olympus iX83 Microscope with Olympus 100x/1.50NA A-Line Apochromatic Objective Lens, dual Photometrics BSI-Express sCMOS cameras and CoolLED pE-300 Light Source. The microscope was controlled with MicroManager 2.0.0 software.

\section{$745 \quad$ Live-cell imaging}

Live-cell imaging experiments were performed at 8 hours (HeLa) or 16 hours (MEFs) postinfection in complete MEM (10\% FBS) in a temperature-controlled chamber at $37^{\circ} \mathrm{C}$. Cells were imaged on a Zeiss Axio Observer spinning-disk microscope equipped with a Plan Achromat 63x/1.4 Ph3 M27 oil lens, an Evolve 512 camera, and a Yokagawa CSUX spinning 750 disk (Galloni et al., 2021; Pfanzelter et al., 2018). The microscope was controlled by the 
bioRxiv preprint doi: https://doi.org/10.1101/2021.10.07.463509; this version posted October 8, 2021. The copyright holder for this preprint

(which was not certified by peer review) is the author/funder, who has granted bioRxiv a license to display the preprint in perpetuity. It is made available under aCC-BY 4.0 International license.

SlideBook software (3i Intelligent Imaging Innovations). For determining recruitment levels of GFP-tagged molecules to the virus, single snapshots of live cells were acquired. To determine virus speed, images were acquired for 50 seconds at $1 \mathrm{~Hz}$.

\section{Image analysis and quantitation}

Quantification of actin tail number and length was performed using two-colour fixed cell images where actin and extracellular virus were labelled. Ten cells were analysed per condition in each independent experiment. The number of actin tails was measured by randomly selecting 25 isolated extracellular virus particles in each image and determining

760 the presence of a tail in the corresponding actin channel. Actin tail length of 8 randomly selected tails per image was measured using the freehand line drawing function in Fiji. To analyse virus motility, two-colour time-lapse movies of HeLa cells stably expressing LifeActiRFP670 infected with the relevant recombinant virus labelled with RFP-A3 were used. The velocity of virus particles in the RFP channel was measured using a Fiji plugin developed by

765 David Barry (the Francis Crick Institute) as previously described (Abella et al., 2016). Bona fide actin-based virus motility was verified manually using the corresponding iRFP670 channel. Five movies were analysed per condition, and speeds from 30 particles were measured in each independent experiment. pY132 antibody intensity was analysed in twocolour fixed cell images where actin was co-labelled. Raw integrated density of the antibody

770 signal was measured at the tip of actin tails after local background subtraction using Fiji. Thirty particles were measured per condition in each independent experiment. Recruitment levels of GFP-tagged molecules to the virus was analysed in two-colour live cell images as an intensity ratio to RFP-A3. Cells with many virus particles at the cell periphery were selected for analysis. GFP images were background subtracted using a median filtered 775 image. The ratio of GFP:RFP intensity at peripheral particles was then measured using Fiji. Five images were analysed per condition, and 30 particles were measured in each independent experiment. In Figure 5B, GFP-Nck intensity at extracellular virus particles was measured in fixed cells using a Fiji particle mapping plugin (Wanaguru et al., 2018). 
bioRxiv preprint doi: https://doi.org/10.1101/2021.10.07.463509; this version posted October 8, 2021. The copyright holder for this preprint

(which was not certified by peer review) is the author/funder, who has granted bioRxiv a license to display the preprint in perpetuity. It is made available under aCC-BY 4.0 International license.

\section{Phosphopeptide pulldown assay}

Phosphorylated and non-phosphorylated peptides were synthesised in-house ( 14 : SQHEpYEDPYEPP, SQHEYEDPYEPP; A36: APSTEHIPYDSVAGST, APSTEHIYDSVAGST) containing the relevant Nck-binding sites and an N-terminal biotin tag. These were coupled to streptavidin Dynabeads M-280 (Thermo Fischer Scientific). Uninfected HeLa cells were 785 lysed in a buffer containing 50mM Tris. $\mathrm{HCl}$ pH7.5, $150 \mathrm{mM} \mathrm{NaCl}, 0.5 \mathrm{mM}$ EDTA, 0.5\% NP40, $0.5 \%$ Triton-X and a cocktail of protease and phosphatase inhibitors (1mM orthovanadate, cOmplete (Roche), PHOSstop (Roche)). A postnuclear supernatant was obtained by a $16,000 \mathrm{~g}$ centrifugation for $10 \mathrm{~min}$ at $4^{\circ} \mathrm{C}$. The peptide-coupled beads were incubated with these clarified cell lysates. Unbound proteins were removed from beads in three washes in

790 the same cell lysis buffer. The proteins bound to beads were resolved on an SDS-PAGE and the presence of Nck was determined by immunoblot analysis using anti-Nck antibody (Millipore \#06-288; 1:1000). As a negative control anti-Grb2 (BD Transduction \#610112, 1:3000) was used. HRP-conjugated secondary antibodies were purchased from The Jackson Laboratory.

795

\section{Statistical analysis and figure preparation}

All data are presented as means \pm S.D. For all experiments, means of at least three independent experiments were used to determine statistical significance by a Welch's t-test (comparing only two conditions), Tukey's multiple comparisons test (comparing multiple

800 conditions with each other) or a Dunnett's multiple comparisons test (comparing multiple conditions with a control). All data are represented as SuperPlots to allow assessment of the data distribution in individual experiments (Lord et al., 2020). SuperPlots were generated using the SuperPlotsOfData webapp (Goedhart, 2021) and graphs showing intrinsic disorder predictions were generated in GraphPad Prism 9. All data were analyzed 805 using GraphPad Prism 9 or the SuperPlotsOfData webapp. Temporal overlays of live imaging data to illustrate virus motility were generated using the temporal colour-code function in Fiji. Schematics were created with BioRender.com. Final figures were assembled using Keynote software. 


\section{$810 \quad$ ACKNOWLEDGEMENTS}

We thank Nicola O'Reilly, Dhira Joshi and Stefania Federico (Peptide Chemistry, the Francis Crick Institute) for synthesizing peptides. We thank Cell Services and Genomics Equipment Park at the Francis Crick Institute for their help with maintaining cell lines and DNA sequencing respectively. We thank members of the Way Laboratory for useful discussions

815 and suggestions, in particular Davide Carra, for nucleating the idea of adding an extra Grb2 site. We also thank Frank UhImann and Neil McDonald (the Francis Crick Institute) for helpful comments on the manuscript. Michael Way was supported by Cancer Research UK (FC001209), UK Medical Research Council (FC001209), and Wellcome Trust (FC001209) funding at the Francis Crick Institute. For the purpose of Open Access, the authors have 820 applied a CC BY public copyright license to any Author Accepted Manuscript version arising from this submission.

\section{AUTHOR CONTRIBUTIONS}

A.B. and M.W. designed the study. A.B. generated the required reagents and performed all experiments and analyses. A.B. and M.W. wrote the manuscript. 


\section{REFERENCES}

Abella, J.V.G., Galloni, C., Pernier, J., Barry, D.J., Kjær, S., Carlier, M.-F., and Way, M. (2016).

840 Isoform diversity in the Arp2/3 complex determines actin filament dynamics. Nat. Cell Biol. $18,76-86$.

Akamatsu, M., Vasan, R., Serwas, D., Ferrin, M.A., Rangamani, P., and Drubin, D.G. (2020). Principles of self-organization and load adaptation by the actin cytoskeleton during clathrinmediated endocytosis. elife 9, e49840.

845 Alberti, S., Gladfelter, A., and Mittag, T. (2019). Considerations and Challenges in Studying Liquid-Liquid Phase Separation and Biomolecular Condensates. Cell 176, 419-434.

Banani, S.F., Lee, H.O., Hyman, A.A., and Rosen, M.K. (2017). Biomolecular condensates: organizers of cellular biochemistry. Nat Rev Mol Cell Biol 27, 1-14.

Banjade, S., Wu, Q., Mittal, A., Peeples, W.B., Pappu, R.V., and Rosen, M.K. (2015).

850 Conserved interdomain linker promotes phase separation of the multivalent adaptor protein Nck. Proc Natl Acad Sci USA 112, E6426-E6435.

Batzer, A.G., Rotin, D., Urena, J.M., Skolnik, E.Y., and Schlessinger, J. (2006). Hierarchy of Binding Sites for Grb2 and Shc on the Epidermal Growth Factor Receptor. Mol. Cell. Biol. 14, 5192-5201.

855 Bienz, M. (2020). Head-to-Tail Polymerization in the Assembly of Biomolecular Condensates. Cell 182, 799-811.

Bladt, F., Aippersbach, E., Gelkop, S., Strasser, G.A., Nash, P., Tafuri, A., Gertler, F.B., and Pawson, T. (2003). The murine Nck SH2/SH3 adaptors are important for the development of mesoderm-derived embryonic structures and for regulating the cellular actin network. Mol. Cell. Biol. 23, 4586-4597.

Blasutig, I.M., New, L.A., Thanabalasuriar, A., Dayarathna, T.K., Goudreault, M., Quaggin, S.E., Li, S.S.C., Gruenheid, S., Jones, N., and Pawson, T. (2008). Phosphorylated YDXV motifs 
and Nck SH2/SH3 adaptors act cooperatively to induce actin reorganization. Mol. Cell. Biol. 28, 2035-2046.

865 Blumenthal, D., and Burkhardt, J.K. (2020). Multiple actin networks coordinate mechanotransduction at the immunological synapse. J. Cell Biol. 219, 301-312.

Bong, Y.S., Park, Y.H., Lee, H.S., Mood, K., Ishimura, A., and Daar, I.O. (2003). Tyr-298 in ephrinB1 is critical for an interaction with the Grb4 adaptor protein. Biochem. J. 377, 499507.

870 Bywaters, B.C., and Rivera, G.M. (2021). Nck adaptors at a glance. Journal of Cell Science 134, jcs258965.

Carlier, M.F., Nioche, P., Broutin-L'Hermite, I., Boujemaa, R., Le Clainche, C., Egile, C., Garbay, C., Ducruix, A., Sansonetti, P., and Pantaloni, D. (2000). GRB2 links signaling to actin assembly by enhancing interaction of neural Wiskott-Aldrich syndrome protein (N-WASp)

875 with actin-related protein (ARP2/3) complex. J. Biol. Chem. 275, 21946-21952.

Case, L.B., Zhang, X., Ditlev, J.A., and Rosen, M.K. (2019). Stoichiometry controls activity of phase-separated clusters of actin signaling proteins. Science 363, 1093-1097.

Chan, K.M.C., Son, S., Schmid, E.M., and Fletcher, D.A. (2020). A viral fusogen hijacks the actin cytoskeleton to drive cell-cell fusion. eLife 9, 3864-19.

880 Cowan, C.A., and Henkemeyer, M. (2018). The SH2/SH3 adaptor Grb4 transduces B-ephrin reverse signals. Nature $413,174-179$.

Davey, N.E. (2019). The functional importance of structure in unstructured protein regions. Curr. Opin. Struct. Biol. 56, 155-163.

Ditlev, J.A., Vega, A.R., Koster, D.V., Su, X., Tani, T., Lakoduk, A.M., Vale, R.D., Mayor, S., 885 Jaqaman, K., and Rosen, M.K. (2019). A composition-dependent molecular clutch between T cell signaling condensates and actin. eLife 8, e42695. 
Dodding, M.P., Mitter, R., Humphries, A.C., and Way, M. (2011). A kinesin-1 binding motif in vaccinia virus that is widespread throughout the human genome. The EMBO Journal 30, 4523-4538.

Donnelly, S.K., Weisswange, I., Zettl, M., and Way, M. (2013). WIP provides an essential link between Nck and N-WASP during Arp2/3-dependent actin polymerization. Curr. Biol. 23, 999-1006.

Finney, H.M., Lawson, A.D.G., Bebbington, C.R., and Weir, A.N.C. (1998). Chimeric Receptors Providing Both Primary and Costimulatory Signaling in T Cells from a Single Gene Product. 895 The Journal of Immunology 161, 2791-2797.

Folkmann, A.W., Putnam, A., Lee, C.F., and Seydoux, G. (2021). Regulation of biomolecular condensates by interfacial protein clusters. Science 373, 1218-1224.

Frese, S., Schubert, W.-D., Findeis, A.C., Marquardt, T., Roske, Y.S., Stradal, T.E.B., and Heinz, D.W. (2006). The Phosphotyrosine Peptide Binding Specificity of Nck1 and Nck2 Src 900 Homology 2 Domains. 281, 18236-18245.

Frischknecht, F., Moreau, V., Röttger, S., Gonfloni, S., Reckmann, I., Superti-Furga, G., and Way, M. (1999). Actin-based motility of vaccinia virus mimics receptor tyrosine kinase signalling. Nature 401, 926-929.

Fuxreiter, M., and Vendruscolo, M. (2021). Generic nature of the condensed states of 905 proteins. Nat. Cell Biol. 23, 587-594.

Galloni, C., Carra, D., Abella, J.V.G., Kjær, S., Singaravelu, P., Barry, D.J., Kogata, N., Guérin, C., Blanchoin, L., and Way, M. (2021). MICAL2 enhances branched actin network disassembly by oxidizing Arp3B-containing Arp2/3 complexes. J. Cell Biol. 220, 1-28.

Goedhart, J. (2021). SuperPlotsOfData-a web app for the transparent display and 910 quantitative comparison of continuous data from different conditions. Mol. Biol. Cell 32, 470-474. 
Hayward, R.D., Leong, J.M., Koronakis, V., and Campellone, K.G. (2006). Exploiting pathogenic Escherichia coli to model transmembrane receptor signalling. Nat. Rev. Microbiol. 4, 358-370.

915 Hiller, G., and Weber, K. (1985). Golgi-Derived Membranes That Contain an Acylated Viral Polypeptide Are Used for Vaccinia Virus Envelopment. J. Virol. 55, 651-659.

Huang, W.Y.C., Alvarez, S., Kondo, Y., Lee, Y.K., Chung, J.K., Lam, H.Y.M., Biswas, K.H., Kuriyan, J., and Groves, J.T. (2019). A molecular assembly phase transition and kinetic proofreading modulate Ras activation by SOS. Science 363, 1098-1103.

920 Huang, W.Y.C., Ditlev, J.A., Chiang, H.-K., Rosen, M.K., and Groves, J.T. (2017). Allosteric Modulation of Grb2 Recruitment to the Intrinsically Disordered Scaffold Protein, LAT, by Remote Site Phosphorylation. J. Am. Chem. Soc. 139, 18009-18015.

Humphries, A.C., Dodding, M.P., Barry, D.J., Collinson, L.M., Durkin, C.H., and Way, M. (2012). Clathrin potentiates vaccinia-induced actin polymerization to facilitate viral spread.

925 Cell Host \& Microbe 12, 346-359.

Humphries, A.C., Donnelly, S.K., and Way, M. (2014). Cdc42 and the Rho GEF intersectin-1 collaborate with Nck to promote N-WASP-dependent actin polymerisation. Journal of Cell Science $127,673-685$.

Jain, S., Wheeler, J.R., Walters, R.W., Agrawal, A., Barsic, A., and Parker, R. (2016). ATPase-

930 Modulated Stress Granules Contain a Diverse Proteome and Substructure. Cell 164, 487498.

Jin, J., and Pawson, T. (2012). Modular evolution of phosphorylation-based signalling systems. Philos. Trans. R. Soc. Lond., B, Biol. Sci. 367, 2540-2555.

Jones, N., Blasutig, I.M., Eremina, V., Ruston, J.M., Bladt, F., Li, H., Huang, H., Larose, L., Li, 935 S.S.C., Takano, T., et al. (2006). Nck adaptor proteins link nephrin to the actin cytoskeleton of kidney podocytes. Nature 440, 818-823. 
Kato, M., and McKnight, S.L. (2017). Cross- $\beta$ Polymerization of Low Complexity Sequence Domains. Cold Spring Harb Perspect Biol 9, a023598-11.

Kato, M., Han, T.W., Xie, S., Shi, K., Du, X., Wu, L.C., Mirzaei, H., Goldsmith, E.J., Longgood, 940 J., Pei, J., et al. (2012). Cell-free formation of RNA granules: low complexity sequence domains form dynamic fibers within hydrogels. Cell 149, 753-767.

Kefalas, G., Jouvet, N., Baldwin, C., Estall, J.L., and Larose, L. (2018). Peptide-based sequestration of the adaptor protein Nck1 in pancreatic $\beta$ cells enhances insulin biogenesis and protects against diabetogenic stresses. J. Biol. Chem. 293, 12516-12524.

945 Keppel, T.R., Sarpong, K., Murray, E.M., Monsey, J., Zhu, J., and Bose, R. (2017). Biophysical Evidence for Intrinsic Disorder in the C-terminal Tails of the Epidermal Growth Factor Receptor (EGFR) and HER3 Receptor Tyrosine Kinases. J. Biol. Chem. 292, 597-610.

Kim, S., Kalappurakkal, J.M., Mayor, S., and Rosen, M.K. (2019). Phosphorylation of nephrin induces phase separated domains that move through actomyosin contraction. Mol. Biol. 950 Cell 30, 2996-3012.

Kumar, M., Gouw, M., Michael, S., Sámano-Sánchez, H., Pancsa, R., Glavina, J., Diakogianni, A., Valverde, J.A., Bukirova, D., Čalyševa, J., et al. (2019). ELM-the eukaryotic linear motif resource in 2020. Nucleic Acids Res. 48, D297-D306.

Leite, F., and Way, M. (2015). The role of signalling and the cytoskeleton during Vaccinia 955 Virus egress. Virus Res. 209, 87-99.

Lemmon, M.A., and Schlessinger, J. (2010). Cell Signaling by Receptor Tyrosine Kinases. Cell $141,1117-1134$.

Lettau, M., Pieper, J., and Janssen, O. (2009). Nck adapter proteins: functional versatility in T cells. Cell Communication and Signaling 7, 1-13. 
960 Li, L., Tibiche, C., Fu, C., Kaneko, T., Moran, M.F., Schiller, M.R., Li, S.S.-C., and Wang, E. (2012a). The human phosphotyrosine signaling network: evolution and hotspots of hijacking in cancer. Genome Research 22, 1222-1230.

Li, P., Banjade, S., Cheng, H.-C., Kim, S., Chen, B., Guo, L., Llaguno, M., Hollingsworth, J.V., King, D.S., Banani, S.F., et al. (2012b). Phase transitions in the assembly of multivalent 965 signalling proteins. Nature 483, 336-340.

Li, X., Lau, A.Y.T., Ng, A.S.N., Aldehaiman, A., Zhou, Y., Ng, P.K.S., Arold, S.T., and Cheung, L.W.T. (2021). Cancer-associated mutations in the p85a N-terminal SH2 domain activate a spectrum of receptor tyrosine kinases. Proc Natl Acad Sci USA 18, 1-11.

Lim, W.A. (2010). Designing customized cell signalling circuits. Nat Rev Mol Cell Biol 11, 393403.

Lim, W.A., and Pawson, T. (2010). Phosphotyrosine signaling: evolving a new cellular communication system. Cell 142, 661-667.

Lin, C.-C., Suen, K.M., Stainthorp, A., Wieteska, L., Biggs, G.S., Leitao, A., Montanari, C.A., and Ladbury, J.E. (2019). Targeting the Shc-EGFR interaction with indomethacin inhibits 975 MAP kinase pathway signalling. Cancer Letters 457, 86-97.

Liu, B.A., and Nash, P.D. (2012). Evolution of SH2 domains and phosphotyrosine signalling networks. Philos. Trans. R. Soc. Lond., B, Biol. Sci. 367, 2556-2573.

Lord, S.J., Velle, K.B., Mullins, R.D., and Fritz-Laylin, L.K. (2020). SuperPlots: Communicating reproducibility and variability in cell biology. J. Cell Biol. 219, 94-10.

980 Lyon, A.S., Peeples, W.B., and Rosen, M.K. (2021). A framework for understanding the functions of biomolecular condensates across scales. Nat Rev Mol Cell Biol 22, 215-235.

Mandiyan, V., O'Brien, R., Zhou, M., Ben Margolis, Lemmon, M.A., Sturtevant, J.M., and Schlessinger, J. (1996). Thermodynamic Studies of SHC Phosphotyrosine Interaction Domain Recognition of the NPXpY Motif. J. Biol. Chem. 271, 4770-4775. 
985 Mayer, B.J. (2015). The discovery of modular binding domains: building blocks of cell signalling. Nat Rev Mol Cell Biol 16, 691-698.

Mayer, B.J., and Yu, J. (2018). Protein Clusters in Phosphotyrosine Signal Transduction. J. Mol. Biol. 430, 4547-4556.

McSwiggen, D.T., Mir, M., Darzacq, X., and Tjian, R. (2019). Evaluating phase separation in 990 live cells: diagnosis, caveats, and functional consequences. Genes \& Dev. 33, 1619-1634.

Moreau, V., Frischknecht, F., Reckmann, I., Vincentelli, R., Rabut, G., Stewart, D., and Way, M. (2000). A complex of N-WASP and WIP integrates signalling cascades that lead to actin polymerization. Nat. Cell Biol. 2, 441-448.

Newsome, T.P., Scaplehorn, N., and Way, M. (2004). Src Mediates a Switch from 995 Microtubule- to Actin-Based Motility of Vaccinia Virus. Science 306, 124-129.

Newsome, T.P., Weisswange, I., Frischknecht, F., and Way, M. (2006). Abl collaborates with Src family kinases to stimulate actin-based motility of vaccinia virus. Cellular Microbiology 8, 233-241.

Nioche, P., Liu, W.-Q., Broutin, I., Charbonnier, F., Latreille, M.-T., Vidal, M., Roques, B., 1000 Garbay, C., and Ducruix, A. (2002). Crystal structures of the SH2 domain of grb2: highlight on the binding of a new high-affinity inhibitor. J. Mol. Biol. 315, 1167-1177.

Nishimura, R., Li, W., Kashishian, A., Mondino, A., Zhou, M., Cooper, J., and Schlessinger, J. (2005). Two Signaling Molecules Share a Phosphotyrosine-Containing Binding Site in the Platelet-Derived Growth Factor Receptor. Mol. Cell. Biol. 13, 6889-6896.

1005 Obenauer, J.C., Cantley, L.C., and Yaffe, M.B. (2003). Scansite 2.0: proteome-wide prediction of cell signaling interactions using short sequence motifs. Nucleic Acids Res. 31, 3635-3641.

Okrut, J., Prakash, S., Wu, Q., Kelly, M.J.S., and Taunton, J. (2015). Allosteric N-WASP activation by an inter-SH3 domain linker in Nck. Proc. Natl. Acad. Sci. U.S.A. 112, E6436E6445. 
1010 Pak, C.W., Kosno, M., Holehouse, A.S., Padrick, S.B., Mittal, A., Ali, R., Yunus, A.A., Liu, D.R., Pappu, R.V., and Rosen, M.K. (2016). Sequence Determinants of Intracellular Phase Separation by Complex Coacervation of a Disordered Protein. Mol. Cell 63, 72-85.

Parkinson, J.E., and Smith, G.L. (1994). Vaccinia Virus Gene A36R Encodes a 43-50 K Protein on the Surface of Extracellular Enveloped Virus. Virology 204, 376-390.

1015 Pfanzelter, J., Mostowy, S., and Way, M. (2018). Septins suppress the release of vaccinia virus from infected cells. J. Cell Biol. 217, 2911-2929.

Pinet, L., Wang, Y.-H., Deville, C., Lescop, E., Guerlesquin, F., Badache, A., Bontems, F., Morellet, N., Durand, D., Assrir, N., et al. (2021). Structural and dynamic characterization of the C-terminal tail of ErbB2: Disordered but not random. Biophys. J. 120, 1869-1882.

1020 Pramatarova, A.E., Ochalski, P.G., Chen, K., Gropman, A., Myers, S., Min, K.-T., and Howell, B.W. (2003). Interacts with Tyrosine-Phosphorylated Disabled 1 and Redistributes in ReelinStimulated Neurons. Mol. Cell. Biol. 23, 7210-7221.

Reeves, P.M., Bommarius, B., Lebeis, S., McNulty, S., Christensen, J., Swimm, A., Chahroudi, A., Chavan, R., Feinberg, M.B., Veach, D., et al. (2005). Disabling poxvirus pathogenesis by 1025 inhibition of Abl-family tyrosine kinases. Nat. Med. 11, 731-739.

Rivera, G.M., Briceño, C.A., Takeshima, F., Snapper, S.B., and Mayer, B.J. (2004). Inducible Clustering of Membrane-Targeted SH3 Domains of the Adaptor Protein Nck Triggers Localized Actin Polymerization. Curr. Biol. 14, 11-22.

Scaplehorn, N., Holmström, A., Moreau, V., Frischknecht, F., Reckmann, I., and Way, M. 1030 (2002). Grb2 and Nck Act Cooperatively to Promote Actin-Based Motility of Vaccinia Virus. Curr. Biol. 12, 740-745.

Schindelin, J., Arganda-Carreras, I., Frise, E., Kaynig, V., Longair, M., Pietzsch, T., Preibisch, S., Rueden, C., Saalfeld, S., Schmid, B., et al. (2012). Fiji: an open-source platform for biological-image analysis. Nat Meth 9, 676-682. 
1035 Shi, T., Niepel, M., McDermott, J.E., Gao, Y., Nicora, C.D., Chrisler, W.B., Markillie, L.M., Petyuk, V.A., Smith, R.D., Rodland, K.D., et al. (2016). Conservation of protein abundance patterns reveals the regulatory architecture of the EGFR-MAPK pathway. Sci Signal 9, rs6.

Sigismund, S., Avanzato, D., and Lanzetti, L. (2017). Emerging functions of the EGFR in cancer. Mol Oncol 12, 3-20.

1040 Smith, M.J., Hardy, W.R., Murphy, J.M., Jones, N., and Pawson, T. (2006). Screening for PTB domain binding partners and ligand specificity using proteome-derived NPXY peptide arrays. Mol. Cell. Biol. 26, 8461-8474.

Snapper, S.B., Takeshima, F., Anton, I., Liu, C.-H., Thomas, S.M., Nguyen, D., Dudley, D., Fraser, H., Purich, D., Lopez-llasaca, M., et al. (2001). N-WASP deficiency reveals distinct 1045 pathways for cell surface projections and microbial actin-based motility. Nat. Cell Biol. 3, 897-904.

Snetkov, X., Weisswange, I., Pfanzelter, J., Humphries, A.C., and Way, M. (2016). NPF motifs in the vaccinia virus protein A36 recruit intersectin-1 to promote Cdc42:N-WASP-mediated viral release from infected cells. Nature Microbiology 1, 1-11.

1050 Songyang, Z., and Cantley, L.C. (1995). Recognition and specificity in protein tyrosine kinasemediated signalling. Trends Biochem. Sci. 20, 470-475.

Stavropoulos, I., Khaldi, N., Davey, N.E., O’Brien, K., Martin, F., and Shields, D.C. (2012). Protein Disorder and Short Conserved Motifs in Disordered Regions Are Enriched near the Cytoplasmic Side of Single-Pass Transmembrane Proteins. PLoS ONE 7, e44389-8.

1055 Su, X., Ditlev, J.A., Hui, E., Xing, W., Banjade, S., Okrut, J., King, D.S., Taunton, J., Rosen, M.K., and Vale, R.D. (2016). Phase separation of signaling molecules promotes T cell receptor signal transduction. Science 352, 595-599.

Tompa, P., Davey, N.E., Gibson, T.J., and Babu, M.M. (2014). A Million Peptide Motifs for the Molecular Biologist. Mol. Cell 55, 161-169. 
1060 van der Lee, R., Buljan, M., Lang, B., Weatheritt, R.J., Daughdrill, G.W., Dunker, A.K., Fuxreiter, M., Gough, J., Gsponer, J., Jones, D.T., et al. (2013). Classification of Intrinsically Disordered Regions and Proteins. Chem. Rev. 114, 6589-6631.

Van Roey, K., Uyar, B., Weatheritt, R.J., Dinkel, H., Seiler, M., Budd, A., Gibson, T.J., and Davey, N.E. (2013). Short Linear Motifs: Ubiquitous and Functionally Diverse Protein 1065 Interaction Modules Directing Cell Regulation. Chem. Rev. 114, 6733-6778.

Wagner, M.J., Stacey, M.M., Liu, B.A., and Pawson, T. (2013). Molecular mechanisms of SH2and PTB-domain-containing proteins in receptor tyrosine kinase signaling. Cold Spring Harb Perspect Biol 5, a008987-a008987.

Wanaguru, M., Barry, D.J., Benton, D.J., OReilly, N.J., and Bishop, K.N. (2018). Murine 1070 leukemia virus p12 tethers the capsid- containing pre-integration complex to chromatin by binding directly to host nucleosomes in mitosis. PLoS Pathog 14, 1-40.

Ward, B.M., and Moss, B. (2004). Vaccinia Virus A36R Membrane Protein Provides a Direct Link between Intracellular Enveloped Virions and the Microtubule Motor Kinesin. J. Virol. 78, 2486-2493.

1075 Ward, B.M., Weisberg, A.S., and Moss, B. (2003). Mapping and functional analysis of interaction sites within the cytoplasmic domains of the vaccinia virus $A 33 R$ and $A 36 R$ envelope proteins. J. Virol. 77, 4113-4126.

Ward, C.W., Gough, K.H., Rashke, M., Wan, S.S., Tribbick, G., and Wang, J.-X. (1996). Systematic Mapping of Potential Binding Sites for Shc and Grb2 SH2 Domains on Insulin 1080 Receptor Substrate-1 and the Receptors for Insulin, Epidermal Growth Factor, Plateletderived Growth Factor, and Fibroblast Growth Factor. J. Biol. Chem. 271, 5603-5609.

Weisswange, I., Newsome, T.P., Schleich, S., and Way, M. (2009). The rate of N-WASP exchange limits the extent of ARP2/3-complex-dependent actin-based motility. Nature 458, 87-91. 
bioRxiv preprint doi: https://doi.org/10.1101/2021.10.07.463509; this version posted October 8, 2021. The copyright holder for this preprint

(which was not certified by peer review) is the author/funder, who has granted bioRxiv a license to display the preprint in perpetuity. It is made available under aCC-BY 4.0 International license.

1085 Welch, M.D., and Way, M. (2013). Arp2/3-mediated actin-based motility: a tail of pathogen abuse. Cell Host \& Microbe 14, 242-255.

Wright, P.E., and Dyson, H.J. (2014). Intrinsically disordered proteins in cellular signalling and regulation. Nat Rev Mol Cell Biol 16, 18-29.

Zhao, Y.G., and Zhang, H. (2020). Phase Separation in Membrane Biology: The Interplay

1090 between Membrane-Bound Organelles and Membraneless Condensates. Developmental Cell 55, 1-15. 


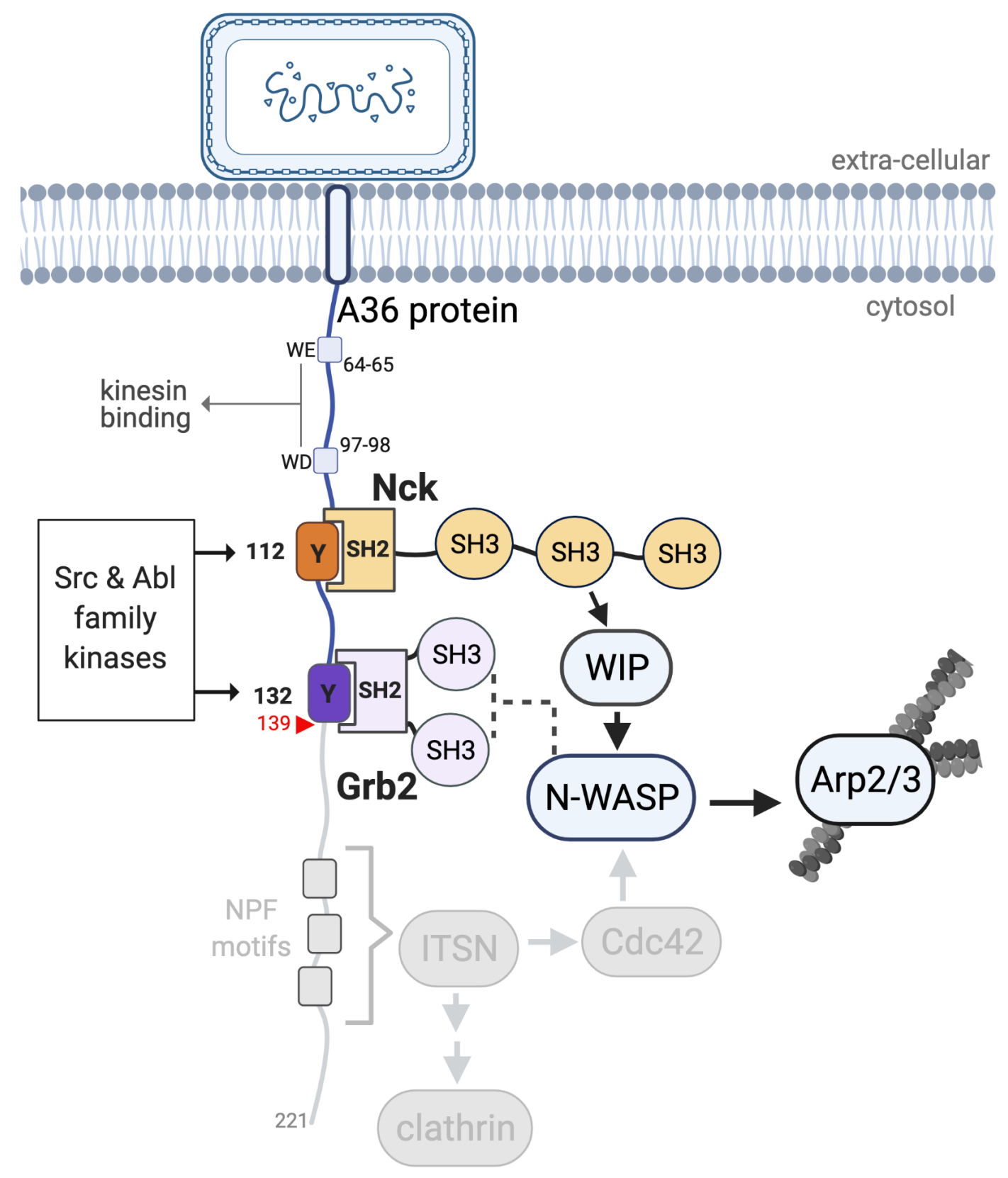

Figure 1 
bioRxiv preprint doi: https://doi.org/10.1101/2021.10.07.463509; this version posted October 8, 2021. The copyright holder for this preprint (which was not certified by peer review) is the author/funder, who has granted bioRxiv a license to display the preprint in perpetuity. It is made

A available under aCC-BY 4.0 Interkititional license.

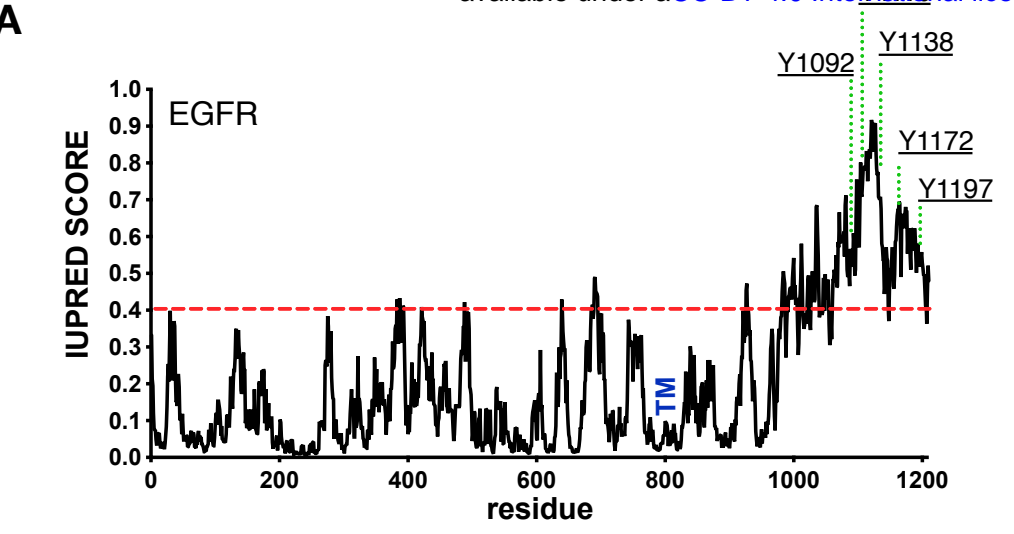

B

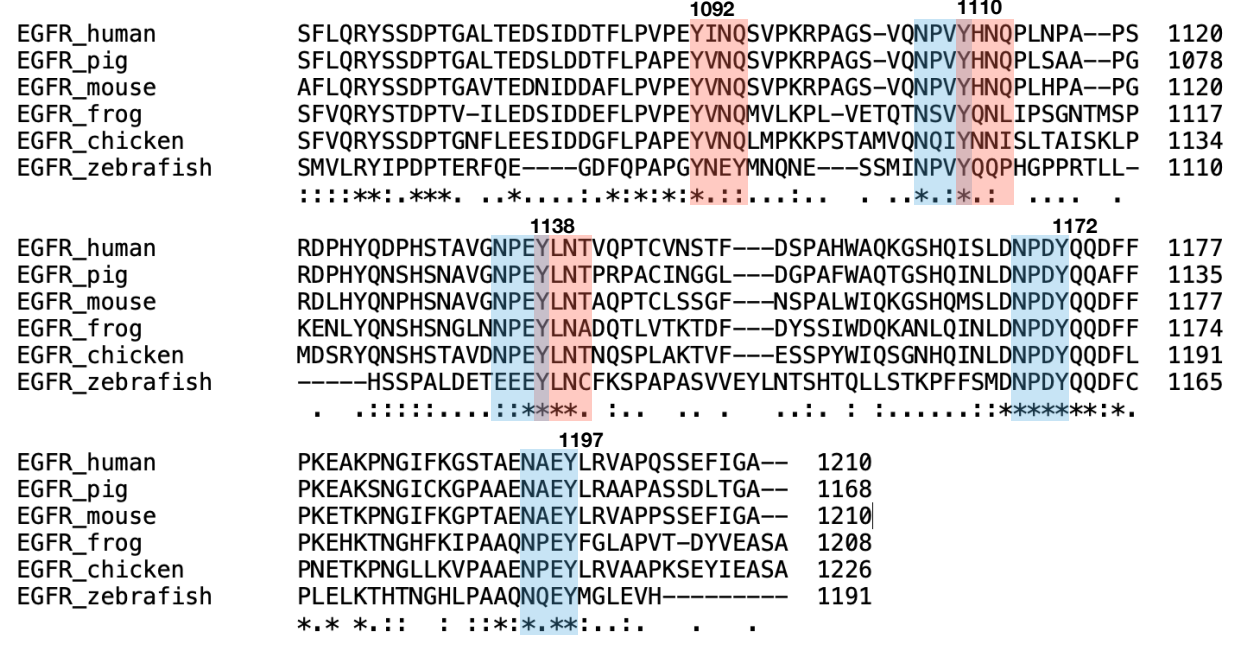

C
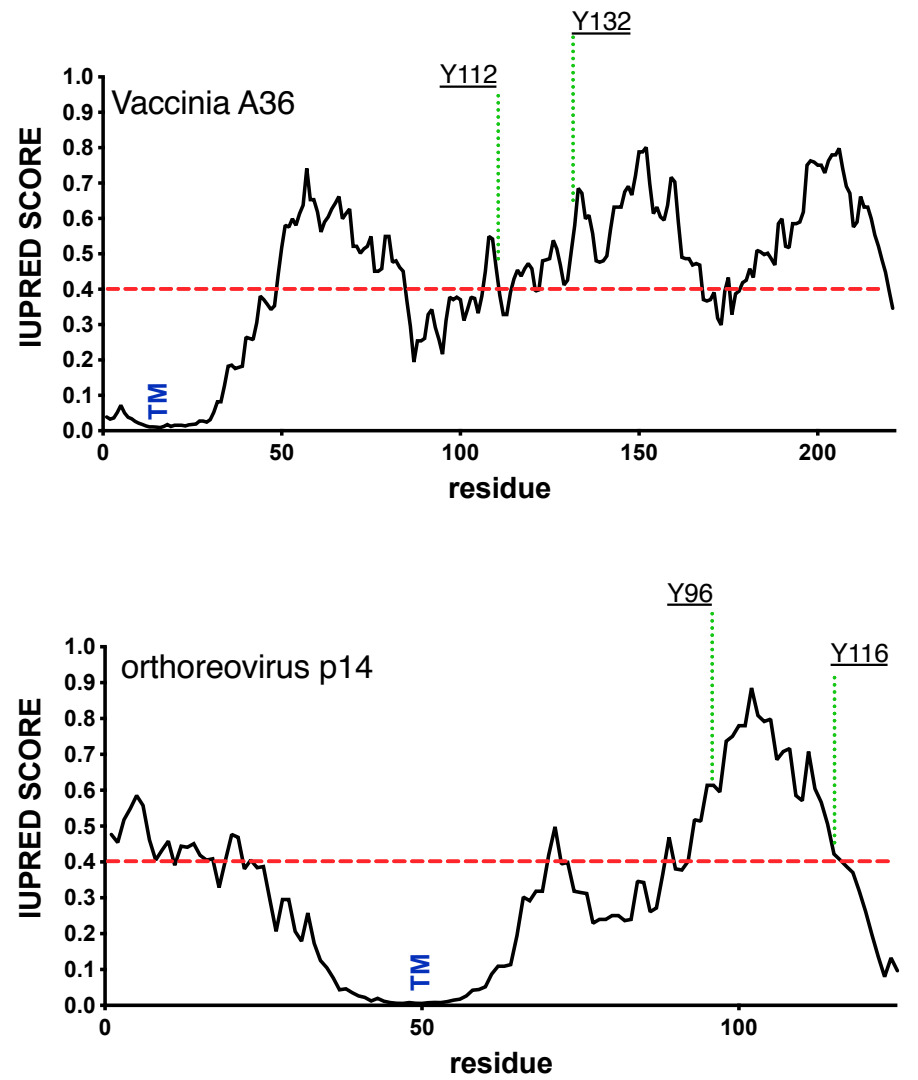

Figure 1 - suppl 1 
bioRxiv preprint doi: https://doi.org/10.1101/2021.10.07.463509; this version posted October 8, 2021. The copyright holder for this preprint (which was not certified by peer review) is the author/funder, who has granted bioRxiv a license to display the preprint in perpetuity. It is made available under aCC-BY 4.0 International license.

A

\section{A36 N-G virus}

...TEHIYDSVAGSTLLINNDRNEQTIYQYNTTVVI

Nck motif

Grb2 motif
A36 G-N virus

...EQTIYQNTTVVILLINNDRNTEHIYDSVAGST

Grb2 motif

Nck motif

B
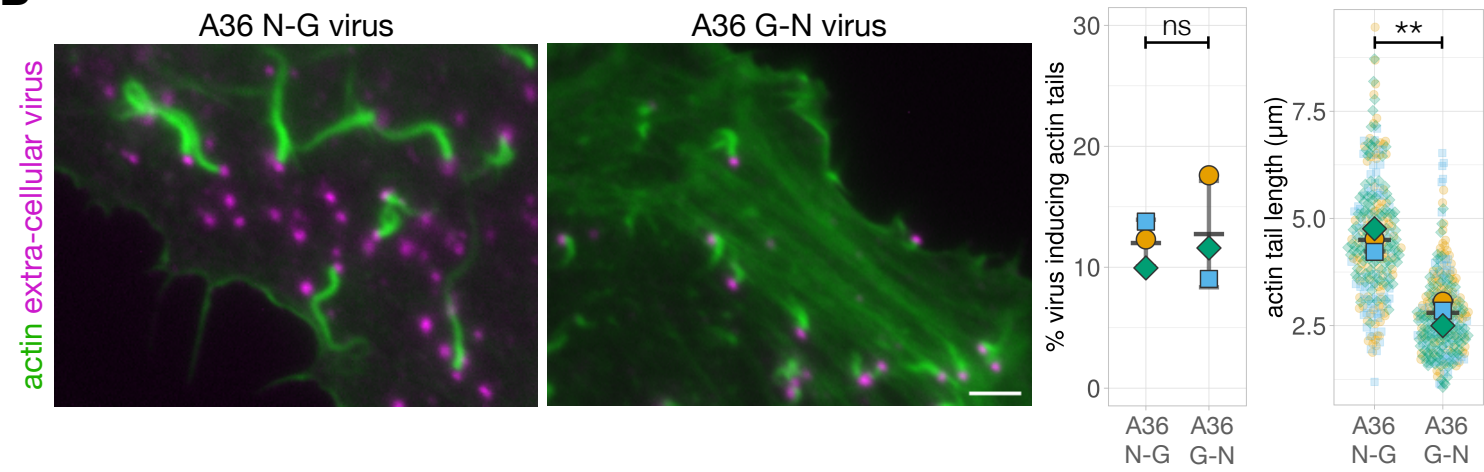

C

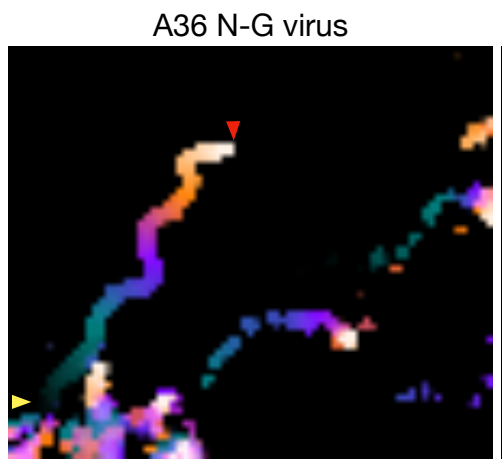

$0 \mathrm{sec}$
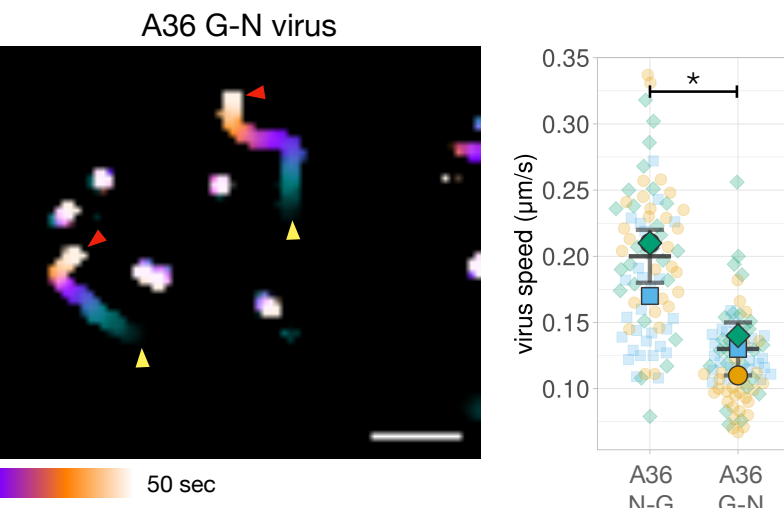

D

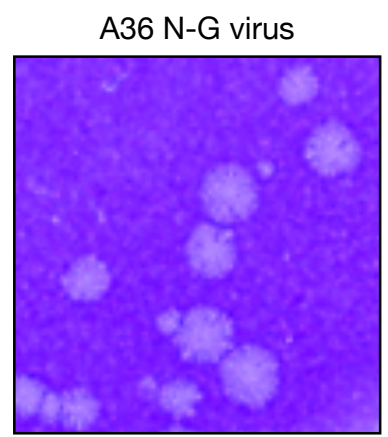

A36 G-N virus
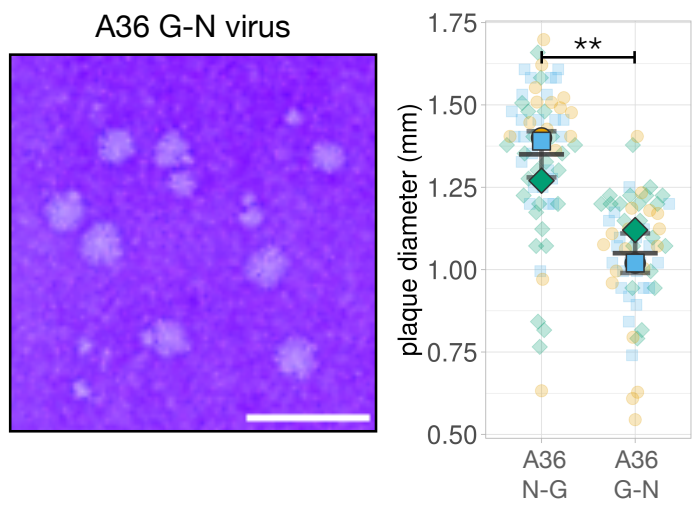

Figure 2 
bioRxiv preprint doi: https://doi.org/10.1101/2021.10.07.463509; this version posted October 8, 2021. The copyright holder for this preprint (which was not certified by peer review) is the author/funder, who has granted bioRxiv a license to display the preprint in perpetuity. It is made

A available under aCC-BY 4.0 International license.

A36 N-G virus
...TEHIYDSVAGSTLLINNDRNEQTIYQNTTVVI Nck motif
Grb2 motif
A36 X-G virus
...TEHIFDSVAGSTLLINNDRNEQTIYQYNTTVVI Grb2 motif

\section{A36 N-X virus \\ ...TEHIYDSVAGSTLLINNDRNEQTIFQNTTVVI Nck motif}

A36 $X-X$ virus

...TEHIFDSVAGSTLLINNDRNEQTIFQNTTVVI

B

\section{A36 $\mathrm{N}-\mathrm{X}$ virus \\ ...TEHIYDSVAGSTLLINNDRNEQTIFQNTTVVI Nck motif}

\section{A36 X-N virus}

...EQTIFQNTTVVILLINNDRNTEHIYDSVAGST Nck motif
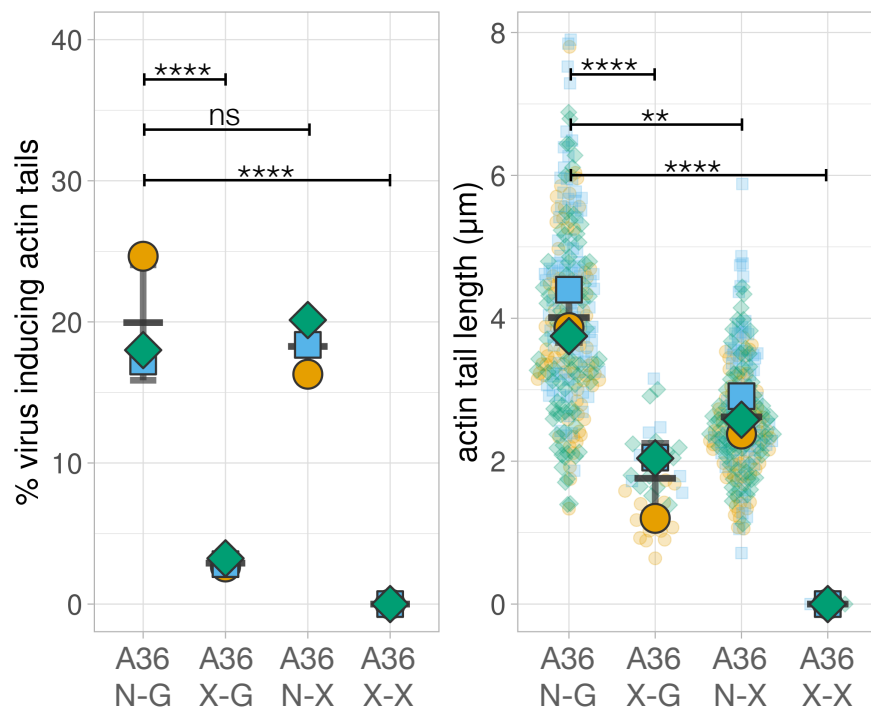

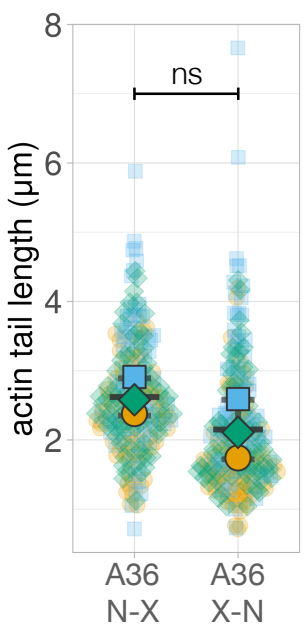

Figure 2 - suppl 1 
bioRxiv preprint doi: https://doi.org/10.1101/2021.10.07.463509; this version posted October 8, 2021. The copyright holder for this preprint (which was not certified by peer review) is the author/funder, who has granted bioRxiv a license to display the preprint in perpetuity. It is made

A

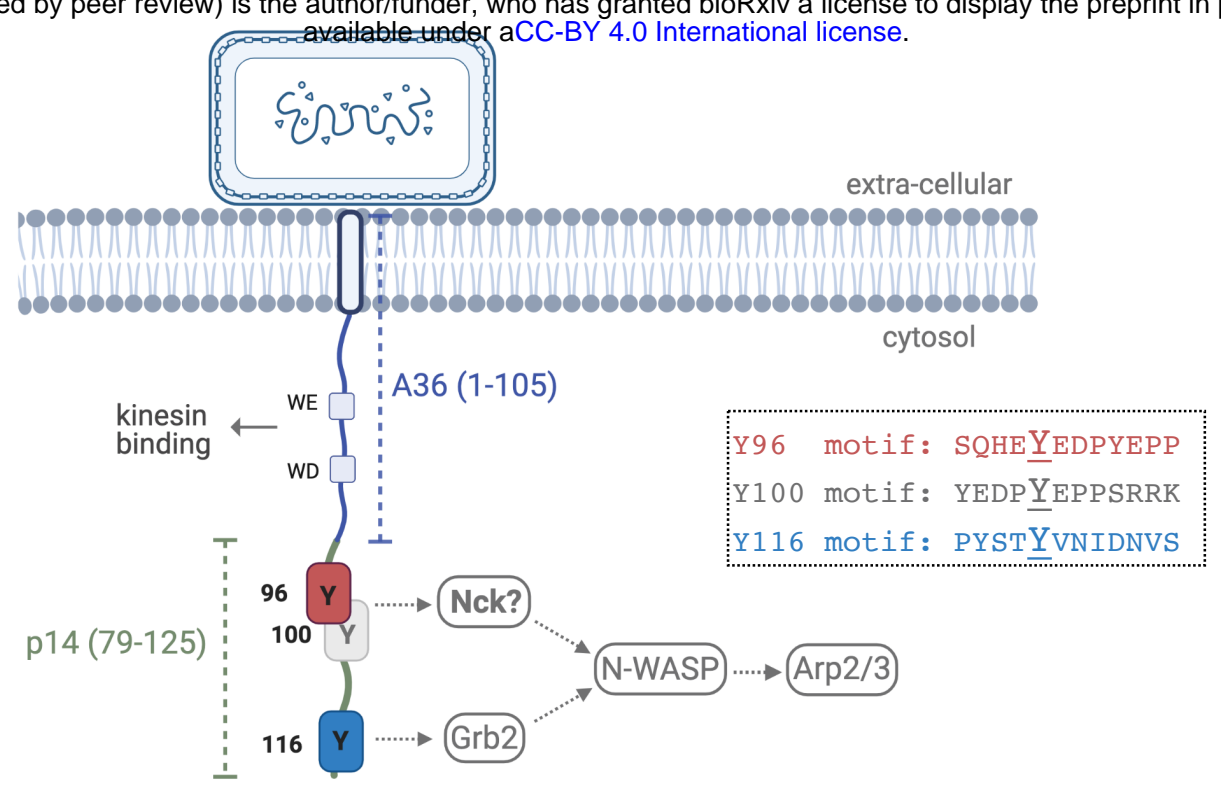

B

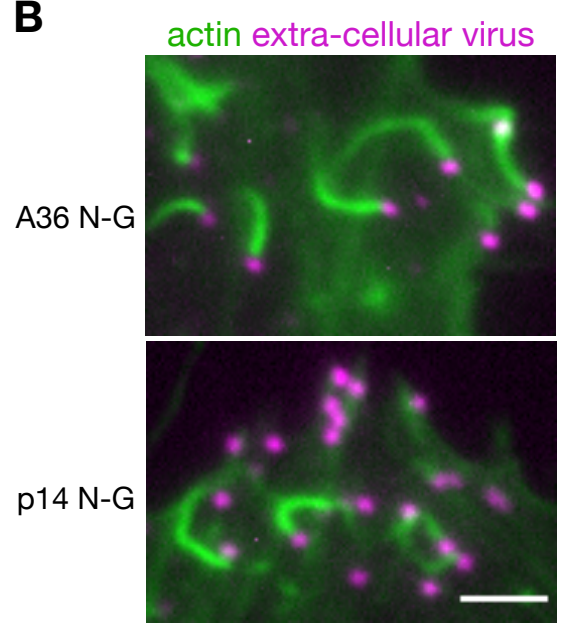

C
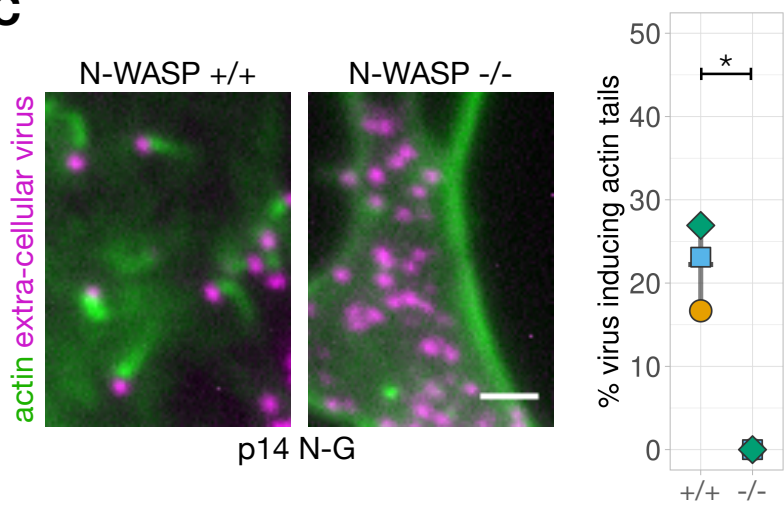

D

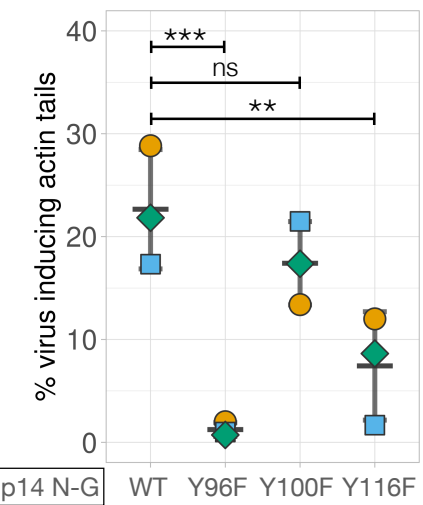

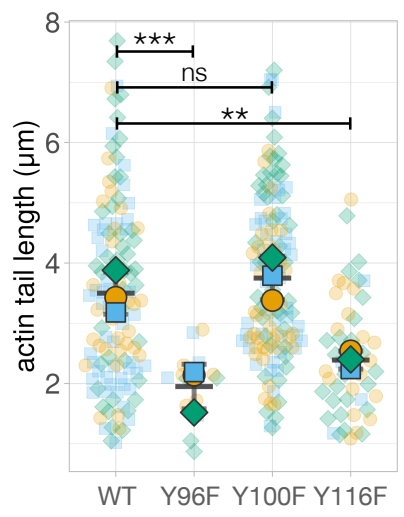

WT Y96F Y100F Y116F
E

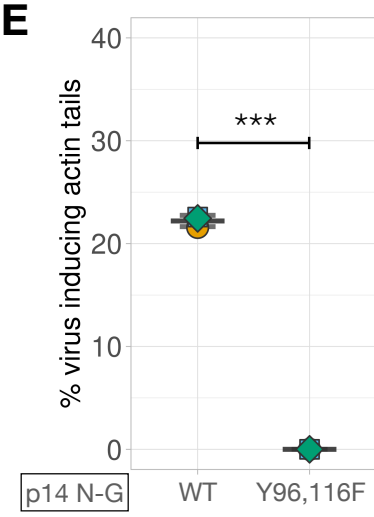

$\mathbf{F}$

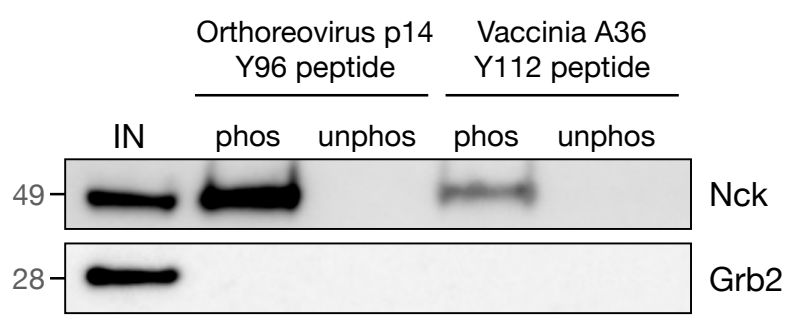

Figure 3 
bioRxiv preprint doi: https://doi.org/10.1101/2021.10.07.463509; this version posted October 8, 2021. The copyright holder for this preprint (which was not certified by peer review) is the author/funder, who has granted bioRxiv a license to display the preprint in perpetuity. It is made available under aCC-BY 4.0 International license.

A actin Nck/Grb2/WIP/N-WASP

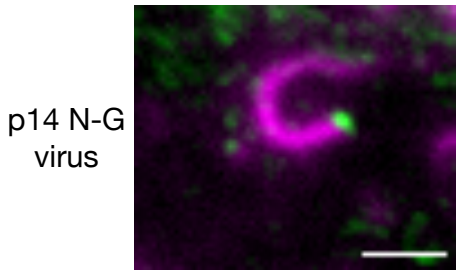

Nck

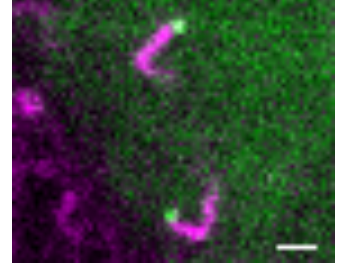

Grb2

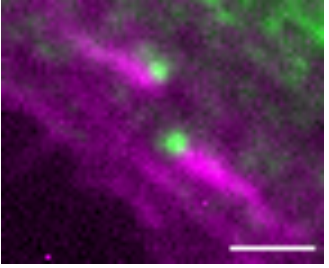

WIP

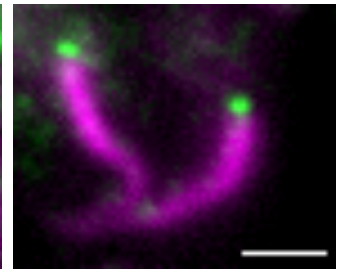

N-WASP

B

p14 N-G virus

...SQHEYEDPYEPPSRRKPPPPPYSTYYNIDNVSAI Nck motif

Grb2 motif p14 G-N virus

...PYSTYVNIDNVSSRRKPPPPSQHEYEDPYEPPAI Grb2 motif

Nck motif
C
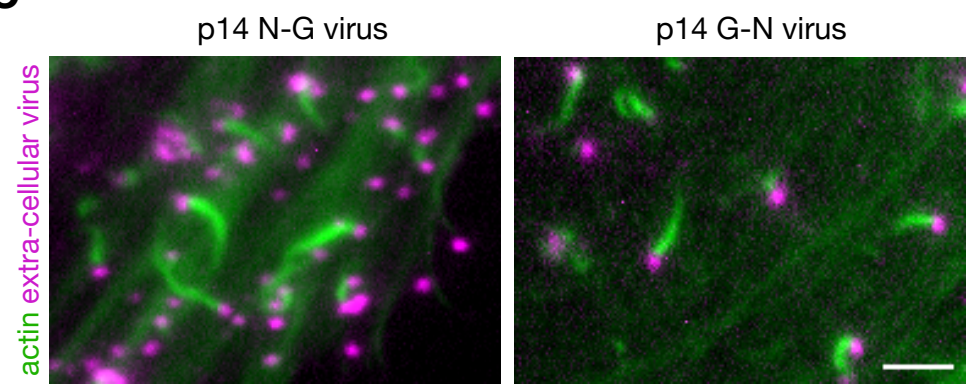

D

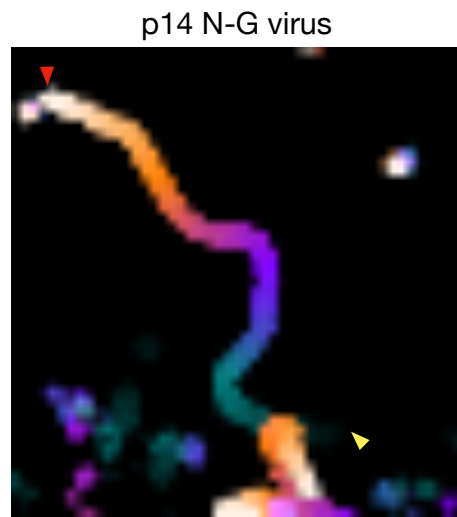

$0 \mathrm{sec}$ p14 G-N virus

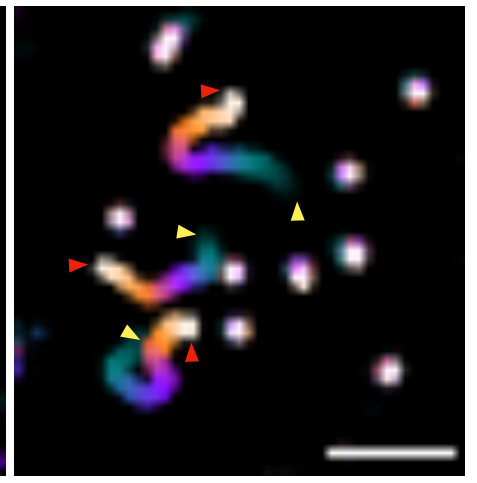

$50 \mathrm{sec}$
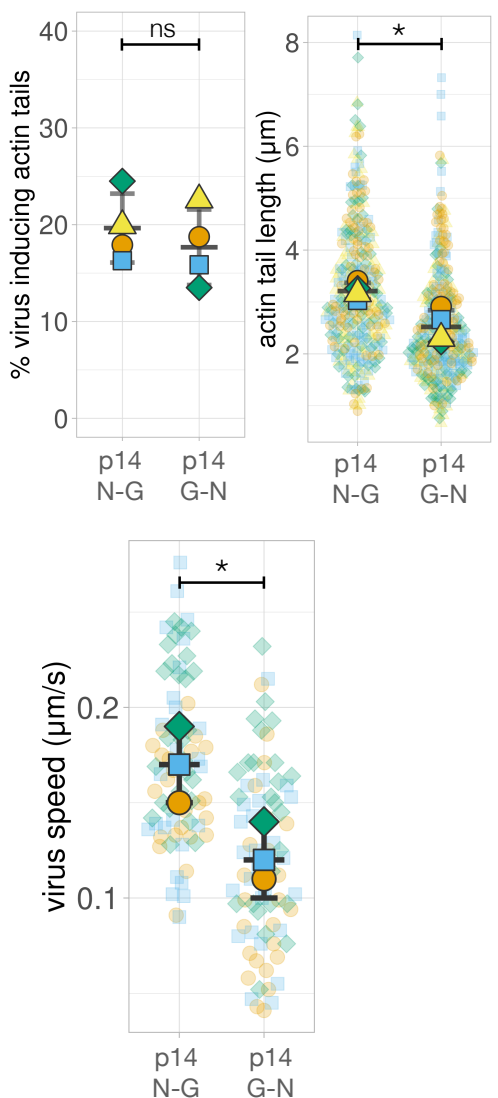

E

p14 N-G virus

p14 G-N virus
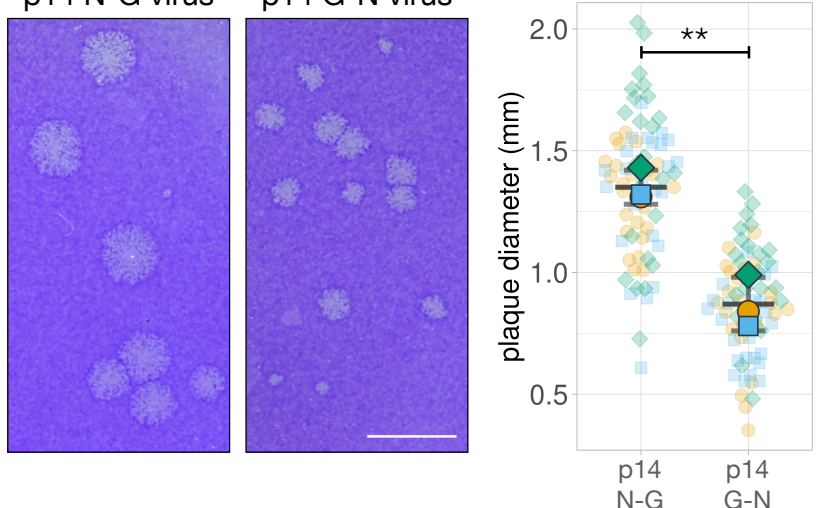

Figure 4 


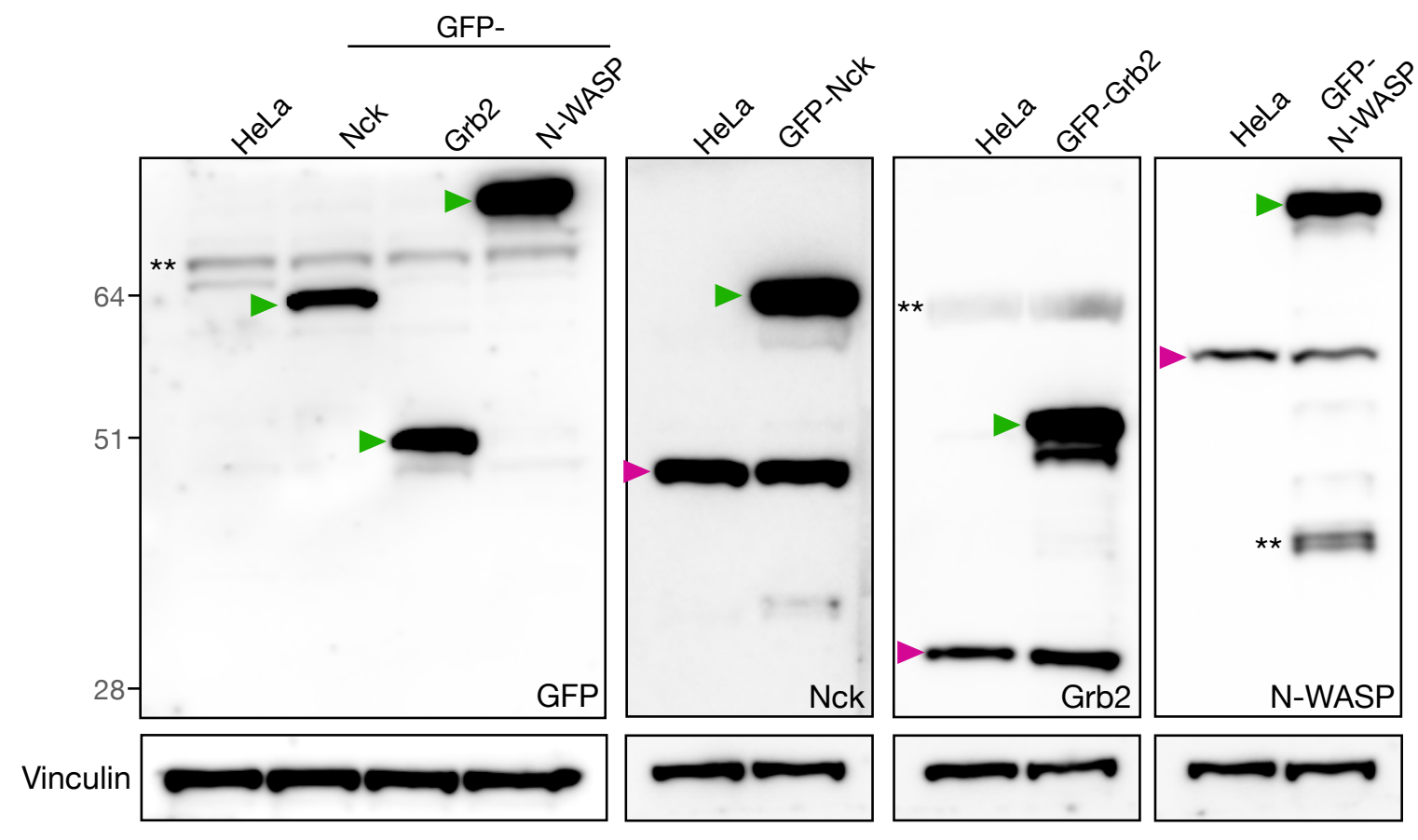

Figure 4 - suppl 1 
bioRxiv preprint doi: https://doi.org/10.1101/2021.10.07.463509; this version posted October 8, 2021. The copyright holder for this preprint (which was not certified by peer review) is the author/funder, who has granted bioRxiv a license to display the preprint in perpetuity. It is made available under aCC-BY 4.0 International license.

A
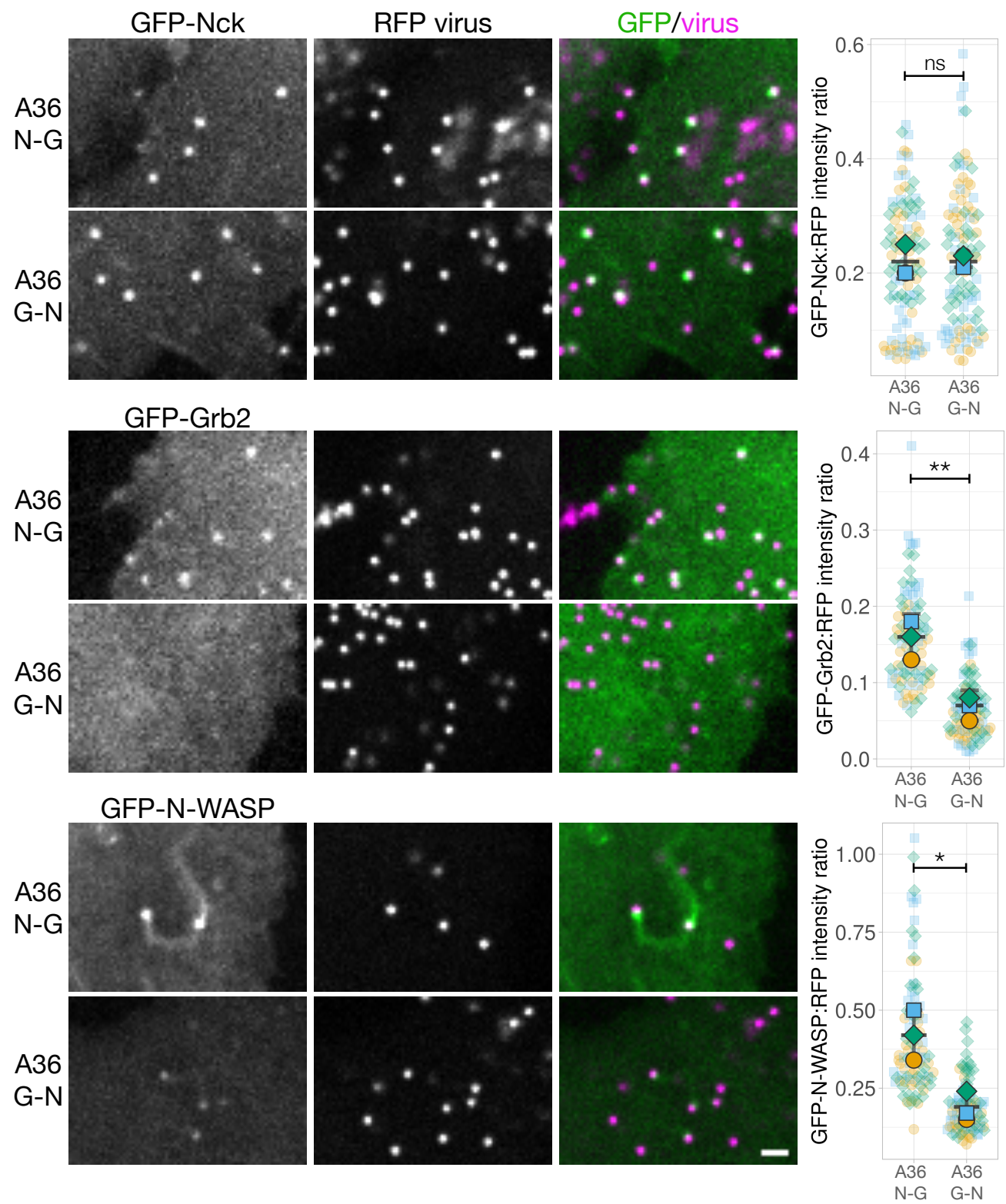

B

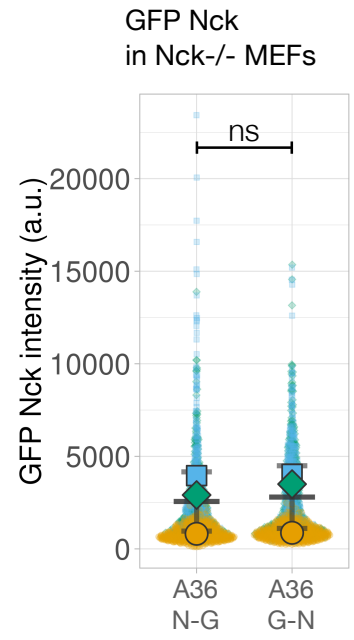

GFP N-WASP

in N-WASP-/- MEFs

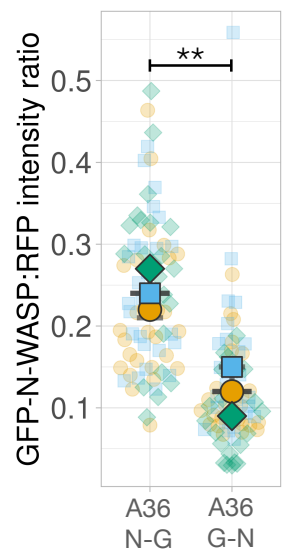

C

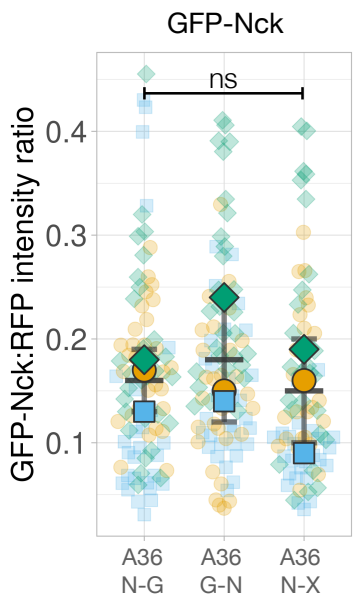

Figure 5 
bioRxiv preprint doi: https://doi.org/10.1101/2021.10.07.463509; this version posted October 8, 2021. The copyright holder for this preprint (which was not certified by peer review) is the author/funder, who has granted bioRxiv a license to display the preprint in perpetuity. It is made available under aCC-BY 4.0 International license.

A HeLa GFP Nck cell line

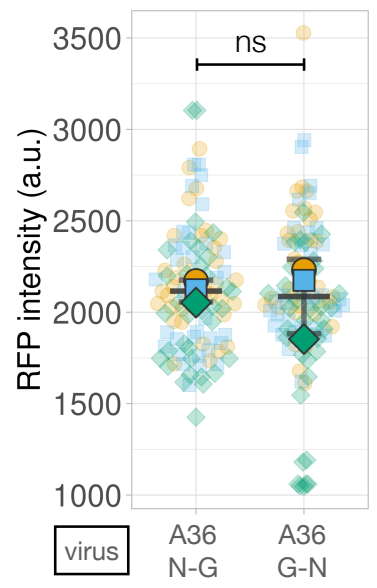

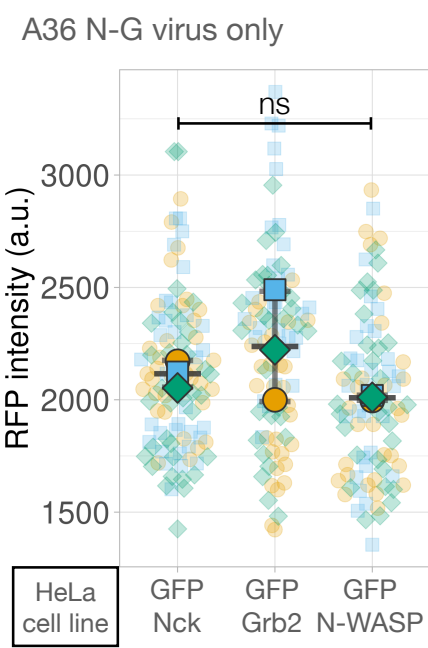

B
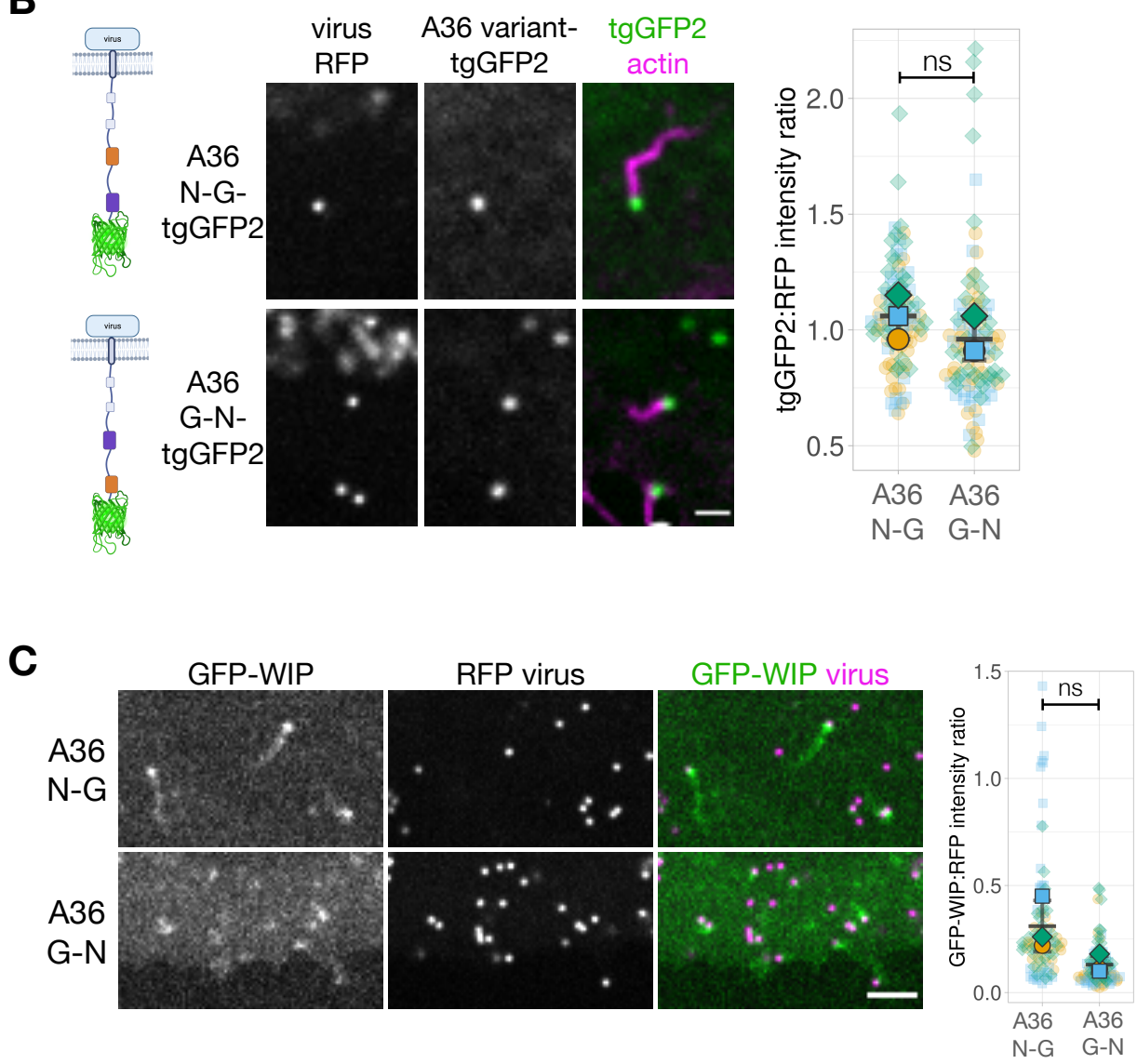

Figure 5 - suppl 1 
bioRxiv preprint doi: https://doi.org/10.1101/2021.10.07.463509; this version posted October 8, 2021. The copyright holder for this preprint (which was not certified by peer review) is the author/funder, who has granted bioRxiv a license to display the preprint in perpetuity. It is made available under aCC-BY 4.0 International license.
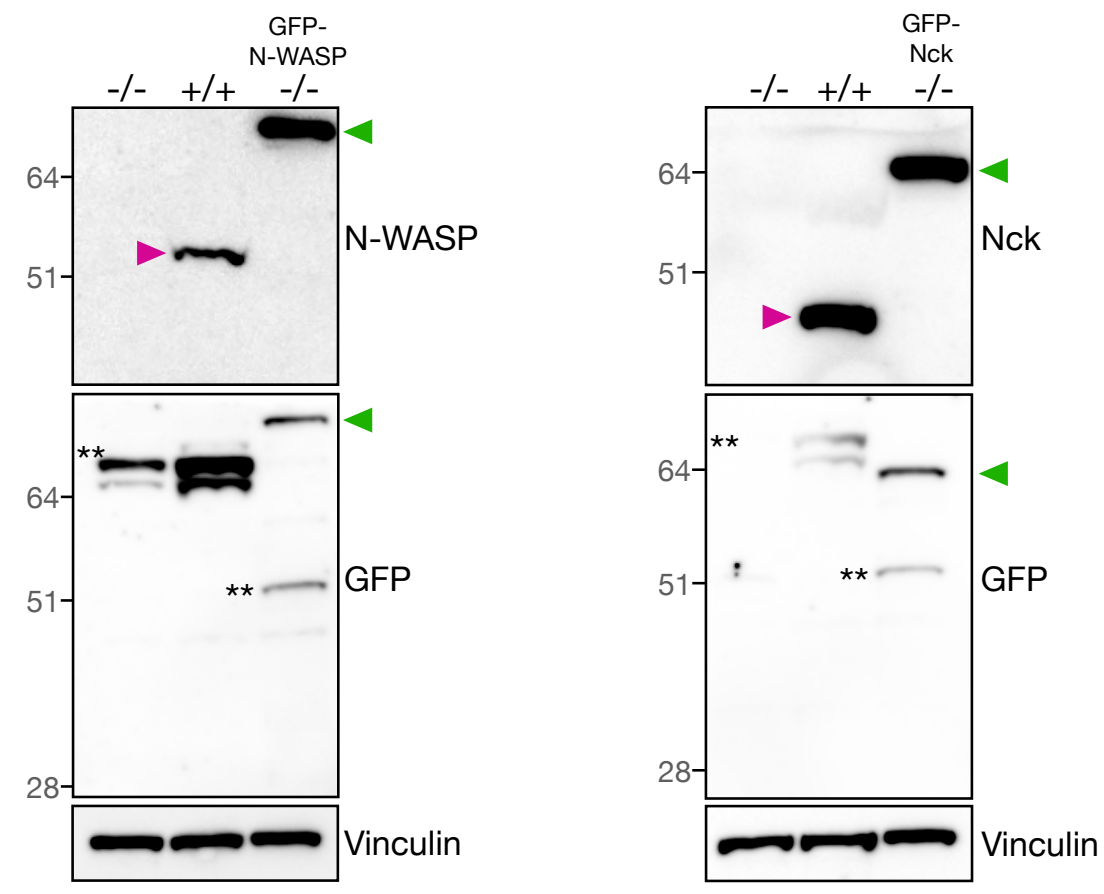

Figure 5 - suppl 2 
bioRxiv preprint doi: https://doi.org/10.1101/2021.10.07.463509; this version posted October 8, 2021. The copyright holder for this preprint (which was not certified by peer review) is the author/funder, who has granted bioRxiv a license to display the preprint in perpetuity. It is made available under aCC-BY 4.0 International license.

A

Grb2 site

phospho-antibody

actin
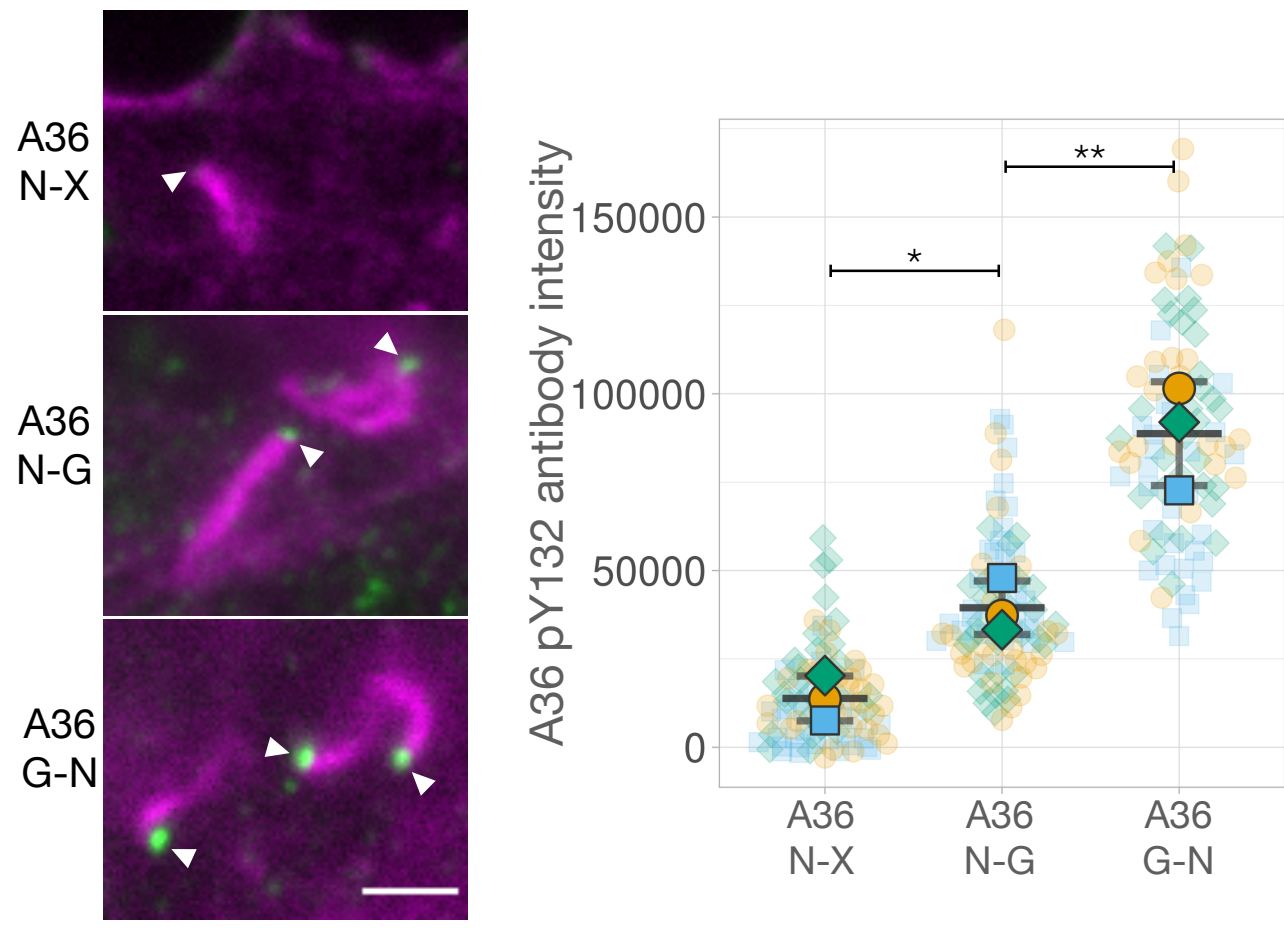

B

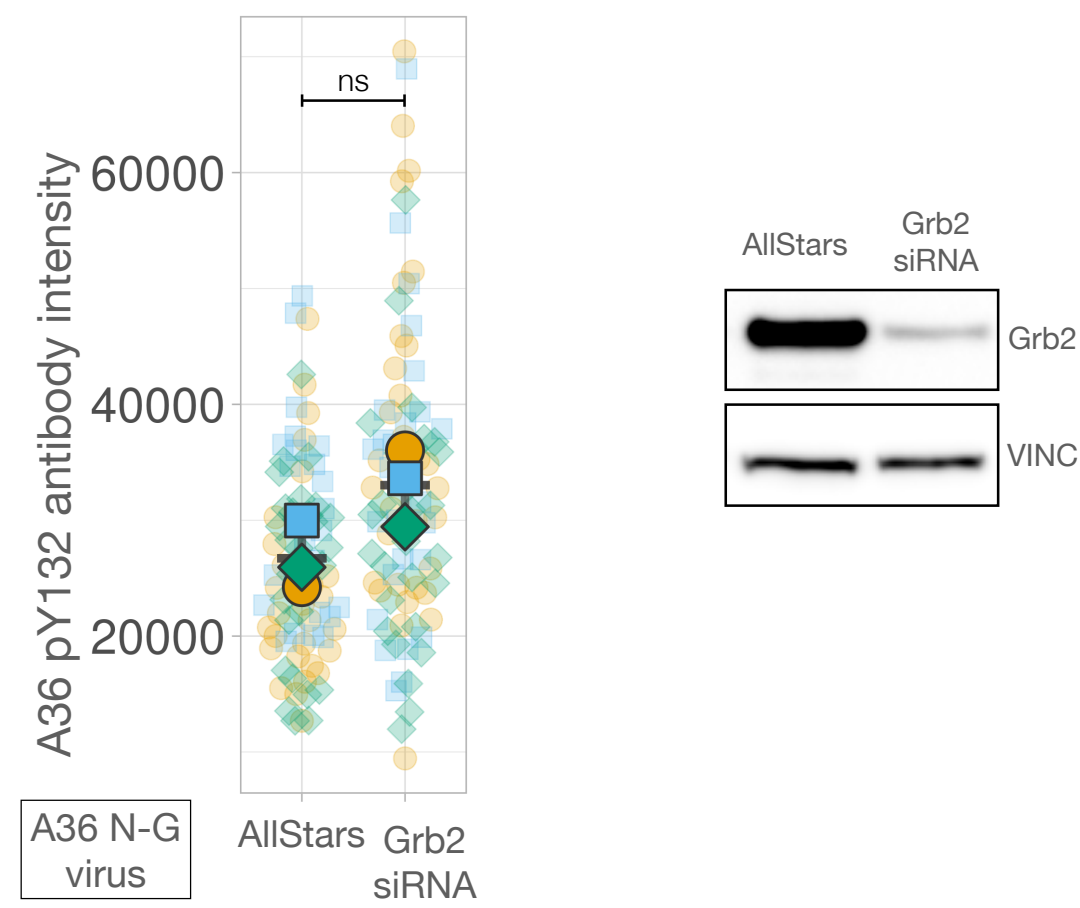

Figure 6 
bioRxiv preprint doi: https://doi.org/10.1101/2021.10.07.463509; this version posted October 8, 2021. The copyright holder for this preprint (which was not certified by peer review) is the author/funder, who has granted bioRxiv a license to display the preprint in perpetuity. It is made

A

\section{A36 N-G virus}

...TEHIYDSVAGSTLLINNDRNEQTIYQNTTVVI Nck motif

Grb2 motif

\section{A36 G-N-G virus}

...EQTIYQNTTVVILLINNDRNTEHIYDSVAGSTLLINNDRNEQTIYYQNTTVVI

Grb2 motif

Nck motif

\section{A36 G-N virus}

...EQTIYQNTTVVILLINNDRNTEHIYDSVAGST

Grb2 motif

Nck motif

A36 G-G-N virus

...EQTIYQQNTTVVILLINNDRNEQTIYQNTTVVILLINNDRNTEHIYDSVAGST

Grb2 motif Grb2 motif Nck motif

B

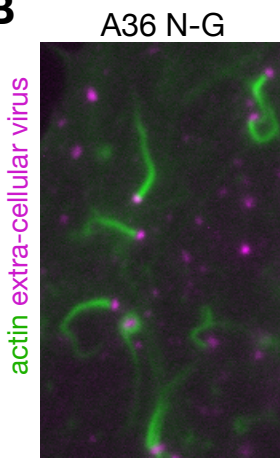

A36 G-N

A36 G-N-G
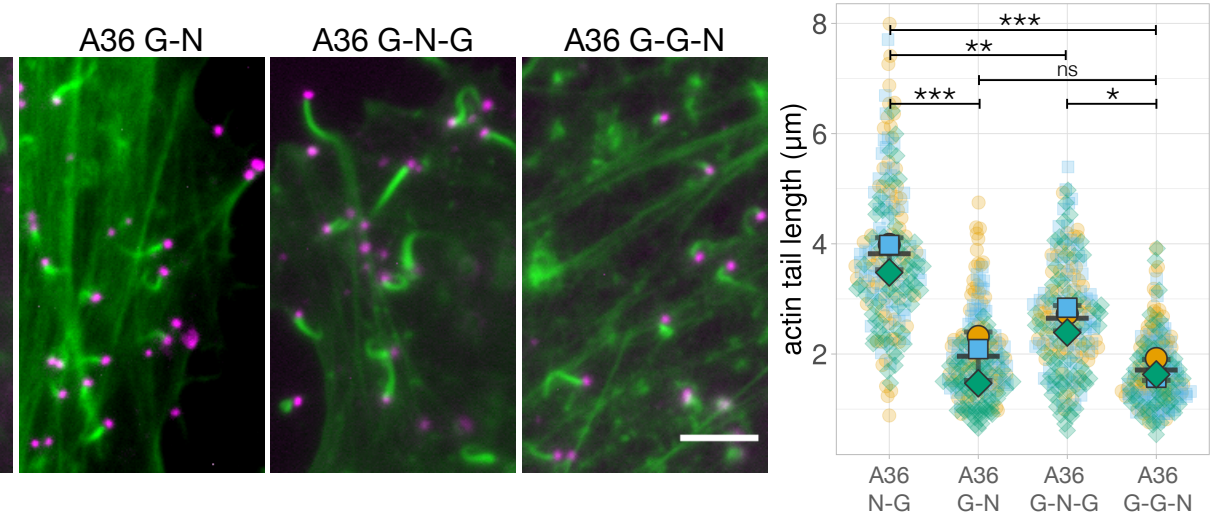

C

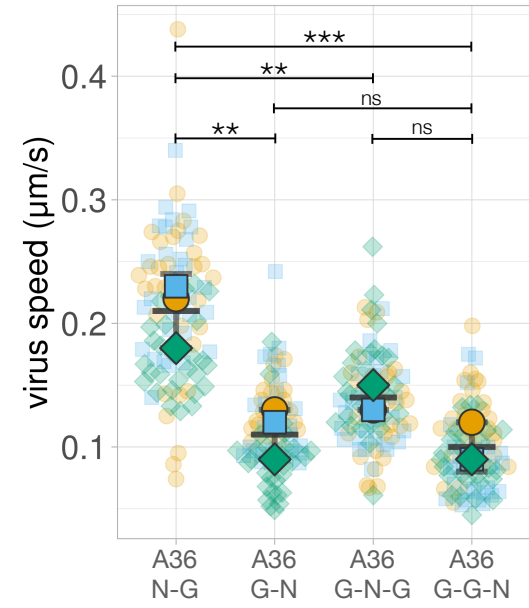

D
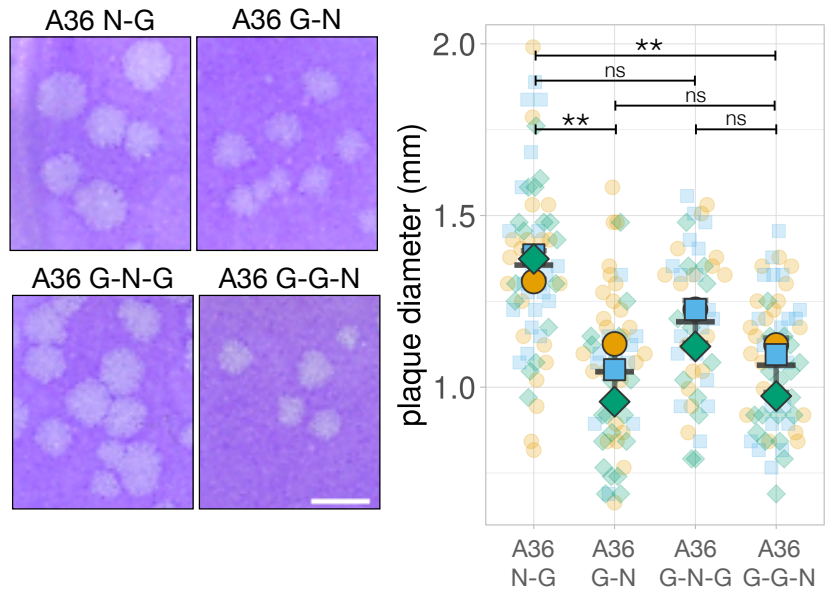

E
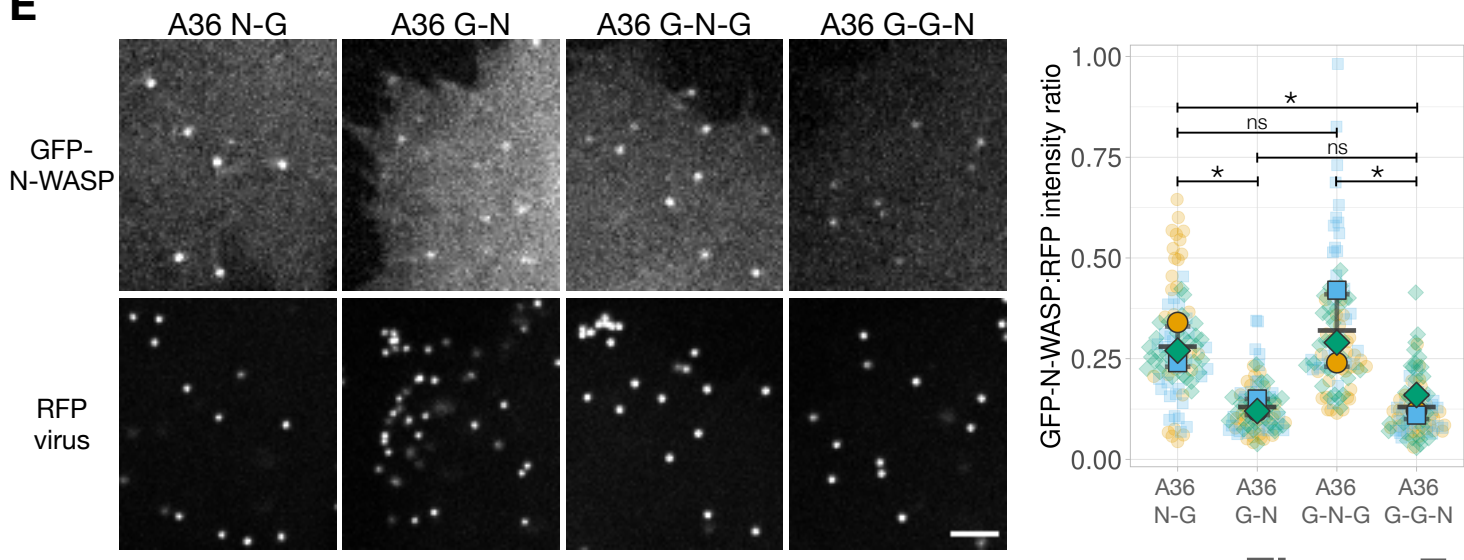

Figure 7 
bioRxiv preprint doi: https://doi.org/10.1101/2021.10.07.463509; this version posted October 8, 2021. The copyright holder for this preprint (which was not certified by peer review) is the author/funder, who has granted bioRxiv a license to display the preprint in perpetuity. It is made available under aCC-BY 4.0 International license.

A

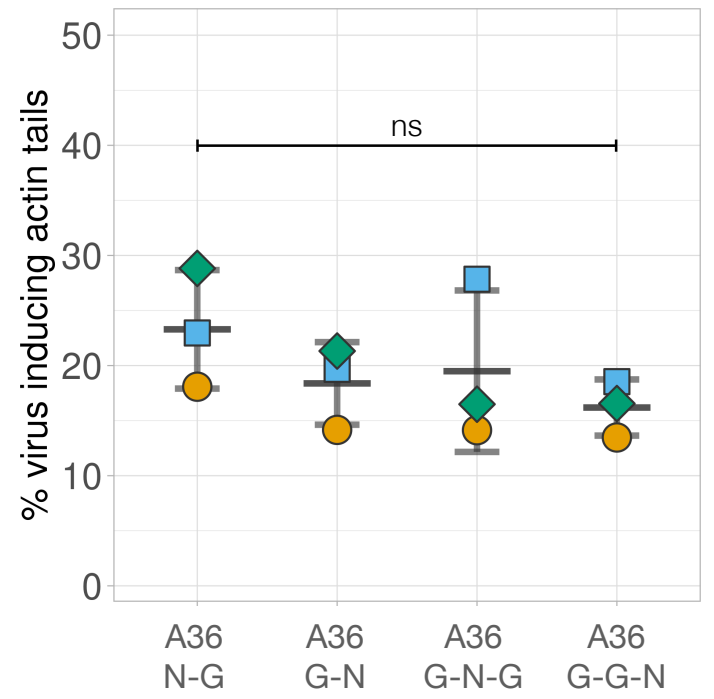

B

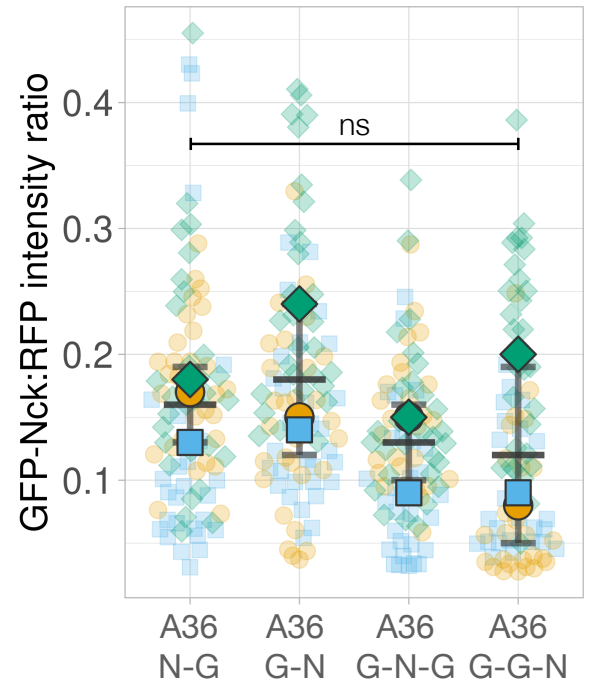

C
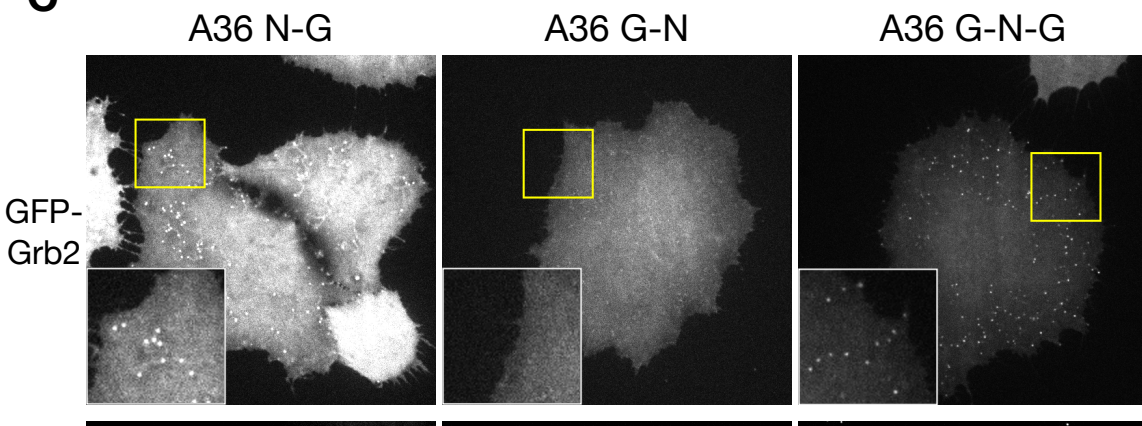

A36 G-G-N
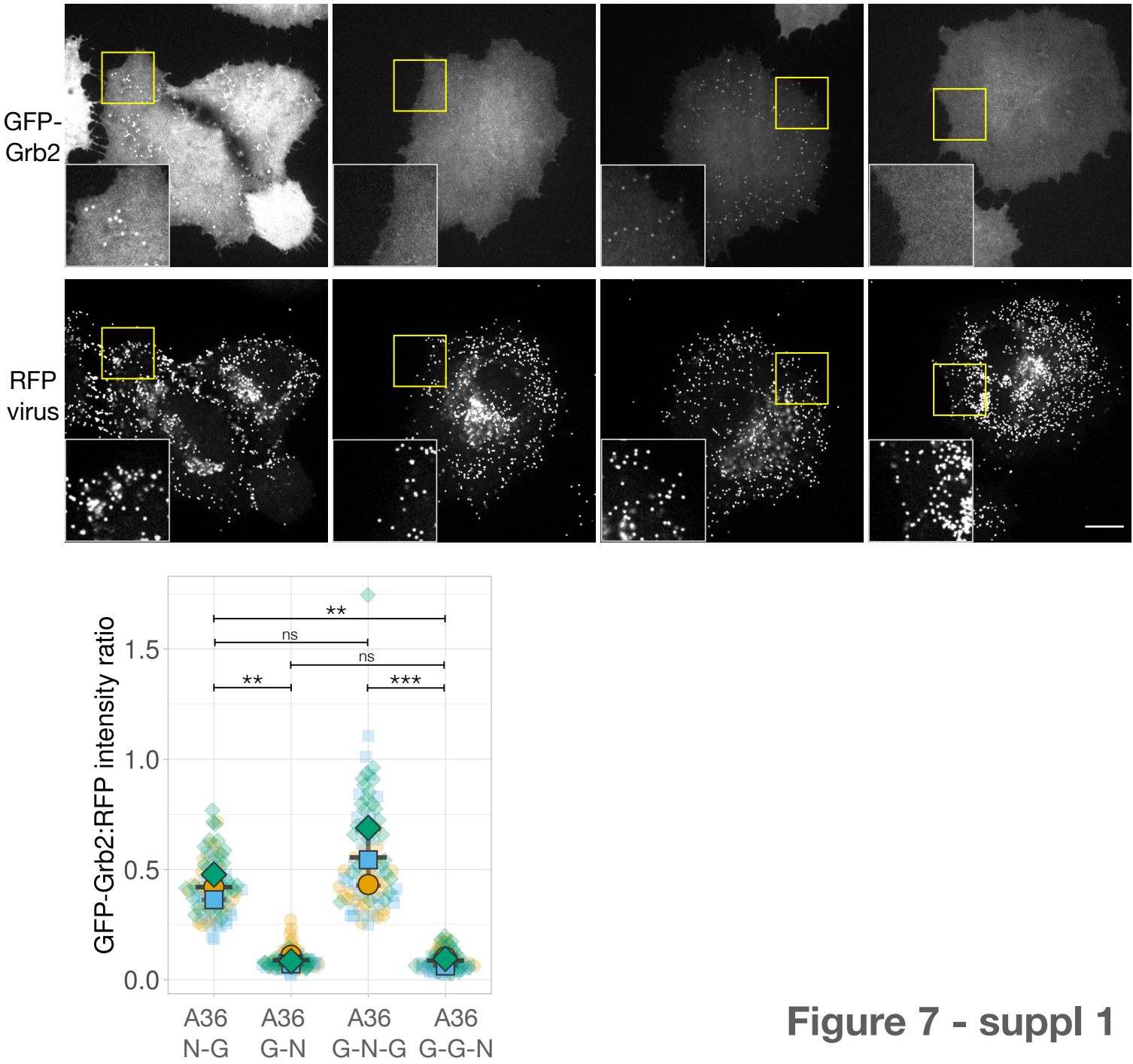

Figure 7 - suppl 1

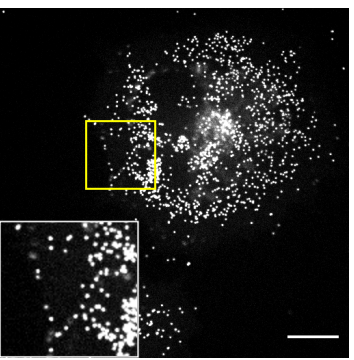

